LBL --25393

DE91 000179

\title{
THERMAL ENERGY STORAGE FOR COOLING OF COMMERCIAL BUILDINGS
}

\author{
Hashem Akbarl \\ Energy Analysis Program \\ Applied Science Division \\ Lawrence Berkeley Laboratory \\ University of Californla \\ Berkeley, CA 94720
}

\author{
Atlla Mertol \\ Sclence Applications Internatlonal Corporation \\ 5150 El Camino Real, Sulte C-31 \\ Los Altos, CA 94022
}

July 1988

Presented at the NATO Advanced Study Institute on Energy Storage Systems: Fundamentals \& Applications, Izmir, Turkey, June 27-July 8, 1988.

This work was supported by the Assistant Secretary for Conservation and Renewable Energy, Office of Buildings and Community Systems, Building Systems Division of the U.S. Department of Energy, and by the U.S. Agency for International Development, through the U.S. Department of Energy under Contract No. DEAC03-76SF00098. 


\title{
THERMAL ENERGY STORAGE \\ FOR COOLING OF COMMERCIAL BUILDINGS
}

\begin{abstract}
The storage of "coolness" has been in use in limited applications for more than a half century. Recently, because of high electricity costs during utiities' peak power periods, thermal storage for cooling has become a prime target for load management strategies. Systems with cool storage shift all or part of the electricity requirement from peak to off-peak hours to take advantage of reduced demand charges and/or off-peak rates. Thermal storage technology applies equally to industrial, commercial, and residential sectors. In the industrial sector, because of the lack of economic inceritives and the custom design required for each application, the penetration of this technology has been limited to a few industries. The perietration rate in the residential sector has been also very limited due to the absence of economic incentives, sizing problems, and the lack of compact packaged systems. To date, the most promising applications of these systems, therefore, appear to be for commercial cooling.

In this report, the current and potential use of thermal energy storage systems for cooling commercial buildings is investigated. In addition, a general overview of the technology is presented and the applicability and cost-effectiveness of this technology for developed and developing countries are discussed.
\end{abstract}

KEYWORDS: chilled water storage / commercial cooling / demand-limited storage / electric load management / full storage / ice storage / partial storage / phase change / thermal energy storage / utility incentives. 
LBL-25393

\section{THERMAL ENERGY STORAGE FOR COOLING OF COMMERCIAL BUILDINGS}

\author{
Hashem Akbari \\ Energy Analysis Program \\ Applied Science Division \\ Lawrence Berkeley Laboratory \\ University of California \\ Berkeley, CA 94720
}

\author{
Atila Mertol \\ Science Applications International Corporation \\ 5:50 El Camino Real, Suite C-31 \\ Los Altos, CA 94022
}

\section{INTRODUCTION}

Cool storage technology was first applied more than half a century ago. However, widespread use of the technology had been limited because of the increased efficiency and reliability of conventional cooling systems and the decreasing cost of producing electricity. Recently, as fossil fuel resources have become increasingly less available and more expensive, many energy conservation strategies have become more viable. (Although nuclear power plants are available for electricity production, their future, at this time, is uncertain due to higher risks involved during nuclear reactor accidents, as demonstrated by the most recent accident in Cheronobyl, USSR, 1986.) Even though energy conservation is highly publicized and studied, peak load energy conservation was not addressed until recently [1-3]. Peak demand is important because utilities are faced either with investing in new generation capacity or purchasing electricity from neighboring utilities - or even from neighboring countries-to accoinmodate expected increases in peak demand. Peak load energy is also more expensive to generate owing to the use of less efficient generators which use more expensive fuels (e.g., oil or gas).

Most conservation strategies are not necessarily designed to make their most significant impact during peak load times. In fact, various conservation strategies may have a positive, neutral, or even regative impact on peak load [4]. To promote load management strategies which reduce utility demand peaks; but increase off-peak electricity sales, utilities have recently begun to (1) offer inceritives to customers who are willing to shift their loads on the utility system from peak to off-peak periods, and (2) design and impose different rate structures so that higher electricity rates are applied to the onpeak hours. Because of the offered incentives and varying rate structures, cool storage technology has re-emerged as the most advanced and cost-effective load management measure for space cooling [5].

Systems with cool storage shift all or part of the electricity requirement from onpeak to off-peak hours and take advantage of reduced demand charges and/or off-peak rates. Cool storage technology has been used in industrial refrigeration processes and in space cooling for both residential and commercial buildings. The most promising applications of these systems, however, appear to be in the cooling of commercial buildings. With the application of the technology, electricity is used when it is least expensive to charge a storage tank. The storage is then used to cool the building during the time 
when electricity is most expensive. Thermal storage can reduce peak electrical demand without sacrificing the comfort of building occupants.

This paper investigates the current and potential use of thermal energy storage systems for cooling commercial buildings. In addition, a general overview of the technology is presented and the applicability and cost-effectiveness of this technology for both developed and developing countries are discussed.

\section{AN OVERVIEW OF COOL STORAGE TECHNOLOGY}

Cool storage systems are often classified according to the storage medium used, i.e., water, ice, and phase change systems. Of these systems, water and ice systems are the most commonly used. Although phase change systems are available, their use has been limited because of the technical problems encountered due to uneven melting. Cool storage systems can also be characterized based on the mode of operation which determines the required storage size to accommodate building peak demand, i.e, partial, demand-limited, and full storage systems. In general, the two types of classifications are inseparable and used together-for example, ice-based full storage, water-based partial storage, etc.

A simple schematic circuit diagram for a thermal storage system with water is given in Ref. [6] and reproduced in Figure 1. The chiller produces cold water during the charging period (lower portion of the loop) and stores it in a storage tank. During discharging periods, the cold water from the storage tank is used to cool the building (upper portion of the loop). With partial storage systems, both loops operate in parallel; during peak hours both the chiller and the storage contribute to cooling the building.

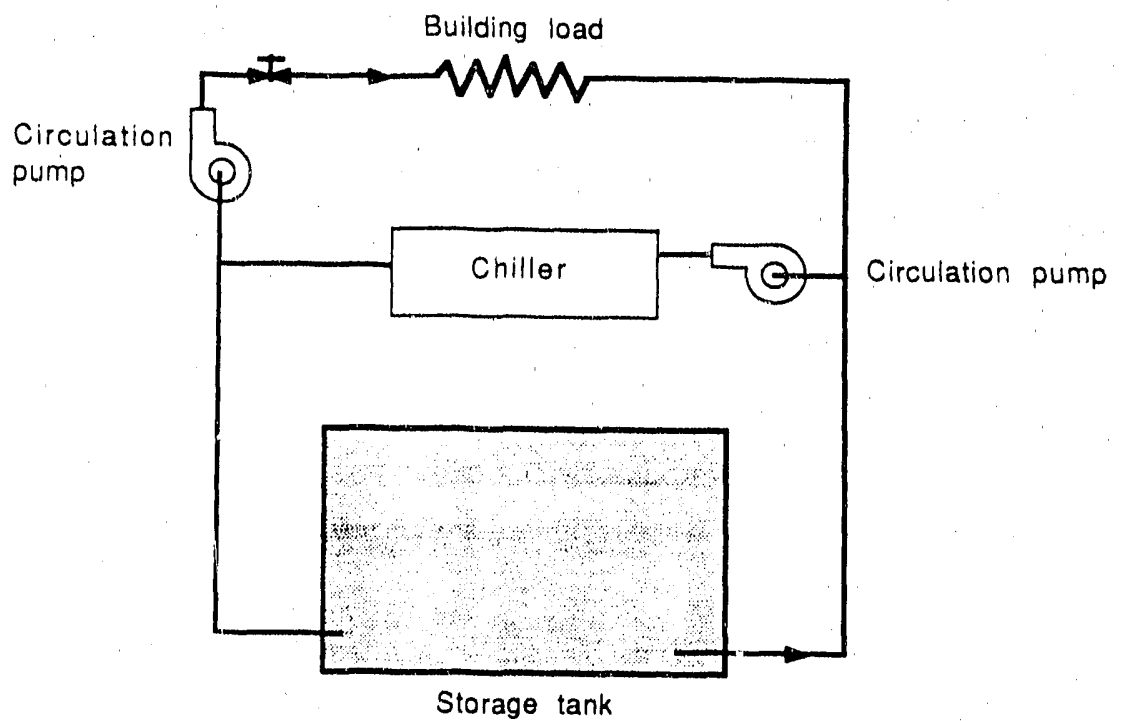

Figure 1. Schematic of Building Circuit for Thermal Energy Storage

In the following sections, factors affecting the design of thermal cool storage systems, such as storage media, operational strategy, and equipment sizing will be 
discussed.

\subsection{Cool Storage Media}

A cool storage system requires a medium to hold cooling energy for later use. Energy can be stored either as sensible (e.g., chilled water) or latent heat (e.g., ice or other phase change materials). One of the important requirements of the storage media is a high thermal capacity so that a large storage volume is not needed. Water meets that requirement and it is also easily available and inexpensive. It is therefore commonly used for cool storage in commercial buildings in the form of either chilled ivater or ice. Other storage media such as phase change materials and clathrates (mixtures of water and refrigerant) are also being developed.

2.1.1. Chilled Water Storage Systems. Chilled water systems are sensible heat storage systems which use the thermal capacitance of water. In general, conventional chilled water cooling systems produce chilled water at about $6^{\circ} \mathrm{C}$. the water is then circulated to cool the building. With the addition of cool storage capability, chilled water is stored at night in a container and circulated during daytime through the cooling coil to accommodate the required comfort level for the building occupants. Because of its similarity to conventional air-conditioning systems, chilled water storage systems have several advantages over the ice and phase change systems [7-9]:

(1) the possibility of using conventional chillers, piping, and air-handling equipment with broad selection and competitive pricing,

(2) the likelihood of using existing chillers in retrofit applications,

(3) the familiarity of engineers in designing systems based on a supply water temperature used in conventional cooling systems,

(4) higher operating efficiencies are realized because storage occurs during nighttime when lower ambient temperatures improve the performance of heat rejection equipment,

(5) the reduction in first costs when larger $\left(<2000 \mathrm{~m}^{3}\right)$ storage tanks are used, and

(6) the reduction in the amount and complexity of training for operating and maintenance personrel owing to the use of conventional equipment and controls.

Chilled water systems are not free of disadvantages, mostly because of the requirement of large storage volumes relative to the other systems. These include [7-9]:

(1) the space required to locate large storage tanks,

(2) the higher thermal losses to the surrounding environment owing to large surface areas,

(3) the requirement of expert construction to avoid cracks and leaks in the storage tank (chilled storage tanks are generally built at the job site; therefore, the stringent standards met in factory-built tanks cannot be applied),

(4) the higher cost of maintenance and water treatment,

(5) the difficulty in adjusting chilled water storage to variations in cooling system sizing because of non-standardized and non-modular tank constructions, and 
(6) the technical difficulties encountered in avoiding mixing of chilled water from the chiller and warmer return water.

A variety of techniques have been used to prevent the mixing of chilled and warmer return water. For example, one of the techniques is to use temperature stratification membranes (or baffles) to separate chilled and return water. In practice, adding membranes have not sufficiently stopped mixing of hot and cold streams; hence, the efficiency of storage systems has not improved. Recently, Wilden and Truman [10] showed that, under normal operating conditions, the performance of storage tanks without baffles can be equal to or greater than the ones with baffles. Another alternative is to use two separate tanks for warm and chilled water [11]. This method would double the cost and space required for storage.

2.1.2. Ice Storage Systems. Water is also used as a phase change storage media to take advantage of a higher storage capacity due to heat from fusion removed during the charging cycle which results in conversion of water to ice. Systems with ice storage are generally classified as either static or dynamic systems, as shown in. Figures 2 and 3 , respectively. In static ice systems, ice is formed on the evaporator surface and remains there until it is melted by the building cooling load. In dynamic systems, ice is formed in one place (i.e, the evaporator) but stored elsewhere (i.e., storage bins or containers).

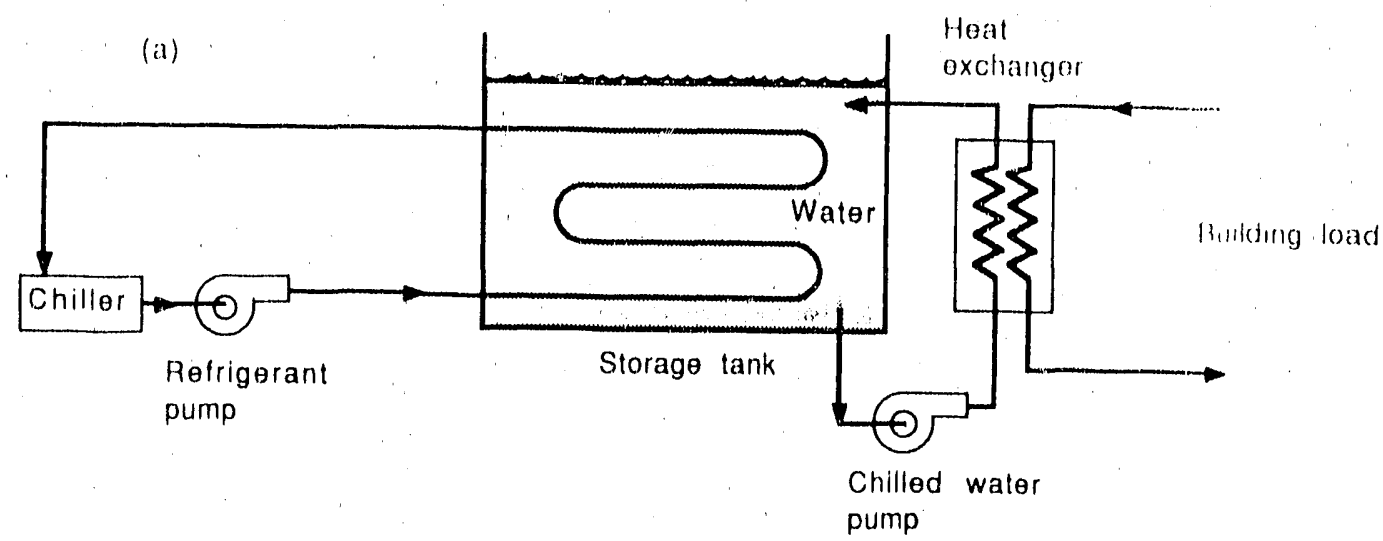

(b)

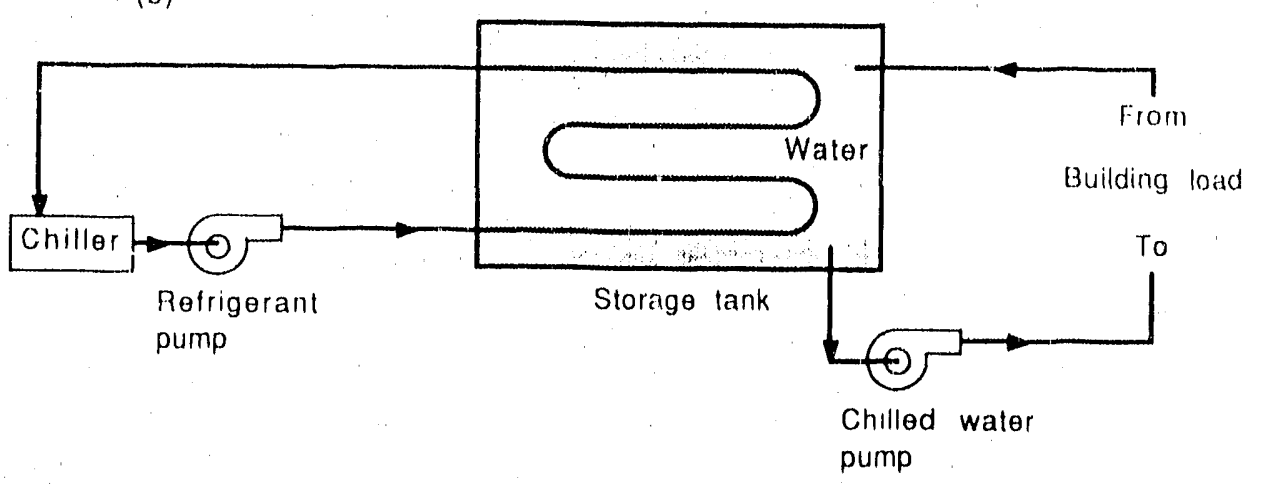

Figure 2. Static Ice Storage Systems: a) open systemı; b) closed system 
Static Ice Systems: Static ice systems are usually known as "ice builders" because of the formation of ice on the outer surfaces of evaporator tubes. These systems may be built as either open or closed as shown in Figures 2(a) and (b), respectively [12]. In open systems, a heat exchanger usually provides a separation between the water surrounding the ice and water circulated through the building, so that contamination of water in the building circuit is eliminated. Since the top of the storage tank is open, the water coming from the tank can be contaminated by the dust particles in the environment. Open storage tanks can be installed on the rooftop to save space. In closed systems, tine storage tank is covered and is therefore suitable for direct burial so that no additional space in the building is required. In a closed system, the cooling demand is satisfied by circulating the water (surrounding the iced coils) directly through the building circuit.

Static systems are also classified according to the type of coolant used (e.g., refrigerant or antifreeze mixture of water and glycol). Direct expansion systems (or DX systems) use refrigerant directly as the coolant while "brine" type systems use an antifreeze fluid. In other words, the ice-holding coils are the evaporators for the refrigeration equipment in a DX ice builder and, in brine ice builders, an antifreeze fluid is cooled by a parkaged chiller to a subfreezing temperature [7].

In general, static ice systems are available in sizes ranging from 48 to 1200 tonriours and all packaged units can be connected to an existing or new building's chilled water system [13].

Dynamic ice Systems: In these systems, ice is formed on the evaporator surface and, once a certain ice thickness is achieved, it is removed and stored in a storage container (cf. Figure 3) [12]. Ice can be removed from the evaporator either by mechanical means or by injecting hot gas into the evaporator plates. Most dynamic systems require that the ice-producing unit be located over the storage container.

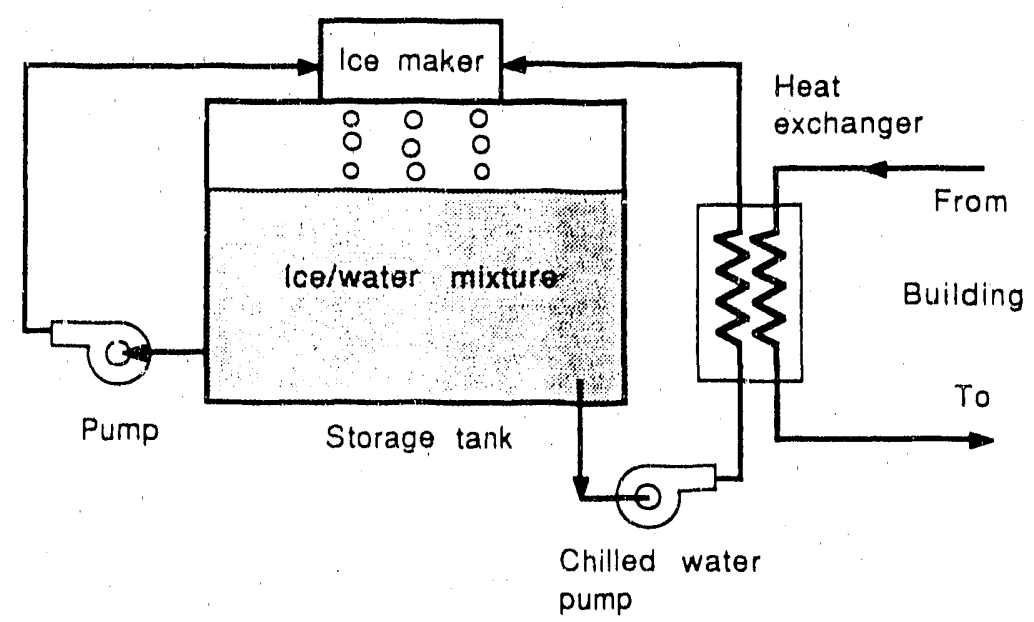

Figure 3. Dynamic Ice Storage System 
Ice systems have several advantages over chilled water systems as a direct consequence of the compactness of storage volume used $[7,8]$ :

(1) larger cooling capacity for a given storage volume,

(2) less space requirement, making it attractive for retrofit applications as well as in new construction,

(3) less thermal losses to the surrounding environment owing to smaller surface area,

(4) fewer design restrictions, for example, elimination of stratification requirement within the storage tank,

(5) greater reliability due to the availability of packaged systems which usually carry manufacturers' warranty,

(6) accurate estimation of the storage cost during the design phase of the project (due to availability of packaged systems),

(7) lower cost of maintenance and water treatment (because of packaged design and less circulating water),

(8) lower storage temperature, reducing the cost of pumping and air distribution (consequently, downsizing pipes, ducts, pumps, etc.), and

(9) modularity of storage tank, permitting the use of factory-built tanks.

Some of the disadvantages of ice systems are $[7,8]$ :

(1) limited selection and less competitive pricing because of lower chiller suction temperature,

(2) reduction in the efficiency of the refrigeration cycle due to the lower suction temperature,

(3) use of unconventional equipment resulting in increase in the amount of training for operating and maintenance personnel, and

(4) existence of some control problems, especially with static systems, owing to the measurement of ice level.

Available in packaged design, ice storage systems have opened the market to small and medium-sized buildings. L.ower initial cost appears to be the reason for this trend.

2.1.3. Phase Change Storage Systems. As an alternative to ice, other phase change materials have been developed to store "coolness" by using heat of fusion during phase change. Salt hydrates-a mixture of water and salt-are frequently used. The mixture is also known as "eutectic salt" and usually freezes in the range of $8-16^{\circ} \mathrm{C}$. The major disadvantage is that most of the eutectic salts melt incongruently or semicongruently so that, during melting, the heavier solid particles settle out. During freezing, the previously settled salt does not recombine with the saturated solution to form the original compound; therefore, the latent heat of the bulk material is reduced [11].

Another alternative is clathrates (or gas hydrates). Clathrates are compounds formed by trapping molecules of gas in a lattice structure of water molecules. This is accomplished by bringing the gas and water into close contact under a proper pressure and temperature [14]. Among the commonly used gases that form clathrates with water are refrigerants R-11 (Trichlorofluoromethane, $\mathrm{CCl}_{3} \mathrm{~F}$ ), R-12 (Dichlorodifluoromethane, 
$\mathrm{CCl}_{2} \mathrm{~F}_{2}$ ) and $\mathrm{R}-22$ (Chlorodifluoromethane, $\mathrm{CHClF}_{2}$ )[15]. The resulting compound usually increases the phase change freezing temperature of the water mixture from 5 to $13^{\circ} \mathrm{C}$.

Phase change materials are either encapsulated in the heat transfer fluid passing outside of capsules to freeze or thaw the solution, or placed inside bulk storage tanks with heat exchanger tubes distributed throughout the compound. The major disadvantage is that most hydrates are highly corrosive; therefore, special care must be taken in the selectlon of container material [11].

\subsection{Operational Strategy}

Most of the storage installations use one of the three basic operational strategies-full, partial, or demand-limited storage. These three strategies are shown in Figure 4, along with a conventional cooling system (see Figure 4(a)) which operates during the sccupied hours of the building to satisty the occupants' comfort level [9].

2.2.1. Full Storage. Full storage minimizes the cost of cooling a building by shifting the use of energy from on-peak to off-peak hours (cf. Figure 4(b)). In full storage systems, the size of the chiller and storage tank are dependent on the time-of-use (TOU) rate schedule of the building. With TOU rate, the primary cooling equipment does not operate during on-peak hours; all of the cooling requirement for the building is supplied from storage. Full storage, therefore, requires larger storage volume than the other operational strategies.

The major advantages and disadvantages of full storage can be summarized as follows:

\section{Advantages}

(1) maximum reduction in utility bill,

(2) use of simple and inexpensive controls, and

(3) well suited for use with existing refrigeration system.

Disadvantages

(1) requirement of largest storage volume and cooling equipment capacity,

(2) highest initial cost of equipment and storage, and

(3) largest space requirement.

Using a full storage strategy, the peak cooling electric demand could be reduced by 80 to 90 percent compared with a conventional cooling system [9]. The reduction in peak load is shown as displaced load in Figure 4(b).

2.2.2. Partial Storage. In partial storage, the chiller is downsized compared to a conventional cooling system and runs at a steady rate over 24 hours. Figure 4(c) illustrates a design load protile for a partial storage system. Compared with a converitional system (cf. Figure 4(a)), the use of a partial storage strategy can significanily reduce building peak load. In partial storage, the storage requirement is smaller than for the full and demand-limited strategies because of the continuous operation of the chiller. Although the system operates continuously, the storage does not meet peak demand, but supplements the full output of the chiller. Partial storage systems have the following advantages over the others [7]: 
(1) minimal required storage and cooling equipment capacity,

(2) minimum space requirement for cooling equipment,

(3) minimum first cost (comparable with the cost of conventional system; downsizing the chiller will pay for the storage cost), and

(4) use of simple and inexpensive controls which reduces training time for maintenance and operating personnel.

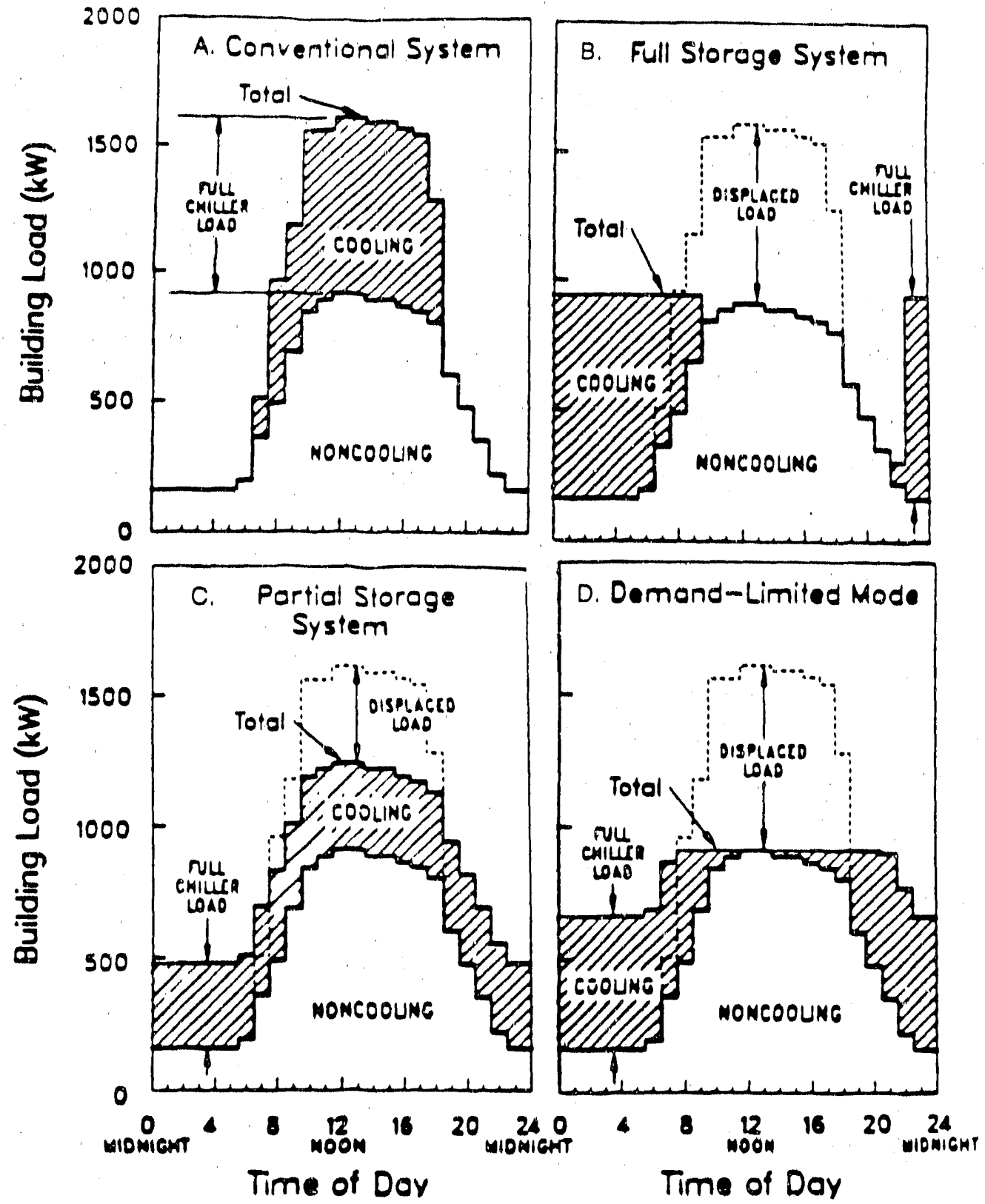

Figure 4. Design Day Hourly Load Profile for a Building with a Conventional Cooling System Compared with Three Cool Storage Strategies. 
The major disadvantage of this strategy is that it does not reduce the customers' utilty bills to the maximum possible extent. Partial storage saves about 40 to 60 percent of peak cooling electric demand [9].

2.2.3. Demand-Limited Storage. A demand-limited storage system is a varlation on partial storage; the chiller runs 24 hours except during hours of maximum non cooling demand as shown in Figure 4(d). This strategy, therefore, requires complicated control systems since the peak demand must be rnet through the storage. A demand-limited strategy is most applicable to bulldings with significant demand charges and short occupancy periods that allow greater storage-charging time [9]. The advantages of demandlimited storage are:

(1) reduction in peak demand,

(2) less chiller and storage capacity than the full storage system, and

(3) less prone to allow accidental peak demand because of the use of sophisticated controls which monitor building demand directly.

\subsection{Cooling System Sizing}

Cooling system size is determined by the maximum cooling demand of the bullding and the operational strategy adopted for the storage, if there is a storage. Conventional cooling systems are designed to satisfy the maximum cooling load of the year based on estimates of the maximum building peak cooling demand. With the inclusion of a storage capability, the cooling system can be downsized (maximally for partial storage) because part of the cooling load is satisfied directly by the chiller and the remaining part from the storage. Therefore, for systems with storage, the sum of the chiller and storage outputs must equal the total daily cooling load of the building. In partial storage, the chiller runs 24 hours, so the cooling load is met over a full day. Hence, the chiller size is reduced to the minimum. With full or demand-limited systems, however, the cooling system size depends on the TOU schedule. For example, in full storage mode, the storage capacity must be large enough to completely meet the daily cooling load of the building. Since the charging of the storage is done during aff-peak hours, the chiller capacity must be selected to fully charge the storage so the daily total cooling load is met.

2.3.1. Chiller Sizing. A conventional chilled water system produces chilled water to meet the building load and operates at or around design temperatures for condenser and evaporator during cooling of the building. Therefore, averaged capacity of a conventional chiller is essentially the rated capacity. Systems with storage perform two different operations: 1) provide direct cooling to the building, and 2) to the storage. For chilled water storage system, the chiller operates at the rated capacity during both direct cooling and charging. For the ice storage system, during direct cooling, the chiller operates at the rated capacity; however, during charging, the capacity drops to about $70 \%$ of the rated capacity [16]. The reduction in capacity is attributable to the evaporator temperature which is usually lower than the design temperature of a nominal chiller. Since the system size depends on the mode of operation (full, partial or demand-limited storage), the operation strategy for the building must be decided in advance of the system sizing. However, to optimize the system size, different design strategies are usually tried. 
Based on the operating mode, the chiller capacity is calculated by dividing the total daily building cooling load by the average capacity in the case of partial or demandlimited strategies, and by the capacity-averaged number of non-peak hours for the full storage strategy $[8,9,13]$. For example, the averaged chiller capacity, CC, for partial storage is calculated as follows [8]:

$$
C C=\left(t_{d c}+f t_{c s}\right) / 24
$$

where $t_{d c}$ is the total number of hours used for direct cooling, $t_{c s}$ is the total number of hours spent to charge the storage, and $f$ is equal to 1 and 0.7 for chilled water and ice storage, respectively. As the chiller averaged-capacity is known, the chiller size, $C$ (in tons), is obtained from:

$$
\mathrm{C}=\mathrm{BL} /(24 \mathrm{CC})
$$

where $B L$. is the total building cooling load given in ton-hours.

2.3.2. Storage Sizing. Storage size depends on both chiller output and number of charging hours available for storage. In partial and full storage strategles, the storage size is given by the product of chiller capacity, numbor of hours used for storage, and the chiller rating while charging the storage. However, in the demand-limited case, part of the cooling load is met directly by the chiller while simultaneously charging the storage. Therefore, storage size is given as the sum of the load met by the storage when the chiller is not operating and the summation of the difference between building load and the chiller output for all other hours $[8,9]$. Note that systems with storage are sized to meet the maximum daily integrated cocling load, whereas conventional systems are sized to meet the annual peak cooling load [13].

\section{MARKET TRENDS}

Cooling is the largest contributor to the summer electric peak demand for the commercial sector. Recent studies [17] indicate that cooling for the commercial sector accounts for 20 to 40 percent of summer peak demand for most of the utilities in the United States. Commercial sector electricity consumption is, therefore, a significant portion of the total electricity use in both developed and developing countries. However, the percentage of electricity consumption in the commercial sector in developing countries is increasing much faster than in the developed countries. For example, the commercial sector electricity use in the United States in 1983 was growing approximately 2.2 percent per year [18]; however, during 1980-1984, the growth of electricity consumption within the commercial sector in Singapore, Malaysia, Indonesia, Philippines, and Thailand averaged at 4.3, 10.5, 3.0, 4.3 and 5.9 percent, respectively [19]. This can be attributed to the higher expansion rate of their economies.

\subsection{The Potential of Cool Storage}

3.1.1. Developed Countries (the United States). The market projection studies for $\mathrm{cool}$ storage performed for the Electric Power Research Institute (EPRI) indicate that cool storage can reduce the commercial sector summer peak by $17 \mathrm{GW}(10 \%)$ by the year 2000 [20]. The estimate was obtained by segmenting the market by new and existing buildings, and by building size, and evaluating the potential for cool storage in each

market segment. This estimate could be significantly affected by the recent development 
and marketing efforts of rooftop packaged urits for cool storage. Based on the sales data for 1985, 625,000 unitary packaged cool storage and 11,780 chillers were sold [21]. By' assuming 5 tons per unitary package and 100 tons per chiller, it can be easily shown thiat package units represented about 73 percent of the commercial cocing market in 1985.

The number of cool storage systems is growing rapidly in states where utilities offer direct incentives to install cool storage for building owners. Recently, Florida Power and Light Company initiated a study in which the market penetration of cool storage technolofjy in both commercial and industrial sectors was estimated for the service area of the utility company [22]. The project was condicted in two phases: (1) exploratory assessmient of cool storage market characteristics, identification of the major factors affecting $\mathrm{cool}$ storage market penetration, and design of a field survey to characterize and quantify the market potential, and (2) analysis of the survey data to quantify the market potential and the incremental market penetration resulting from utility programs and iricentives. To estimate the impact of thermal energy storage, building prototypes were developed from a sample of 300 customers. The sample was drawn from the fourteen building types shown in rable 1.

Table 1: Sample size and megawatis (MW) deferred by cooling storage by building Siratum in year 2001 for rebate incentives program of Florida Power and Light Company [द.2].

\begin{tabular}{|c|c|c|c|c|c|}
\hline Building Type & Sample Size & $\begin{array}{l}\text { New } \\
\text { MW }\end{array}$ & $\begin{array}{c}\text { Megawa } \\
\text { Existing } \\
\text { MW }\end{array}$ & $\begin{array}{l}\text { Deferr } \\
\text { Total } \\
\text { MW }\end{array}$ & $\begin{array}{c}\text { Percent } \\
\%\end{array}$ \\
\hline Large Office Bldg & 40 & 53.1 & 27.9 & 81.0 & 42.1 \\
\hline Shopping Center & 15 & 0.5 & 0.0 & 0.5 & 0.3 \\
\hline Lérge Retail Store & 30 & 23.0 & 7.0 & 29.9 & 15.6 \\
\hline School & 22 & 11.0 & 17.2 & 28.2 & 14.6 \\
\hline Higher Education & 20 & 2.4 & 0.0 & 2.4 & 1.2 \\
\hline Hospital & 20 & 12.2 & 0.0 & 12.2 & 6.3 \\
\hline Hotel & 30 & 6.8 & 0.0 & 6.8 & 3.5 \\
\hline Restaurant & 14 & 0.6 & 0.0 & 0.6 & 0.3 \\
\hline Civic Center & 22 & 1.6 & 0.0 & 1.6 & 0.8 \\
\hline Movie Theater & 14 & 0.0 & 0.0 & 0.0 & 0.0 \\
\hline Church & 17 & 1.5 & 0.0 & 1.5 & 0.8 \\
\hline Food Industry & 18 & 0.0 & 0.0 & 0.0 & 0.0 \\
\hline Apparel, Furn. \& Printing & 18 & 1.3 & 0.0 & 1.3 & 0.7 \\
\hline Assembly Industry & 20 & 22.0 & 4.6 & 26.6 & 13.8 \\
\hline Total & 300 & & & 192.5 & 100.0 \\
\hline
\end{tabular}

A detailed hourly simulation of the loads was performed for each prototypical customer along with a detailed analysis of the potential application of cool storage 
technologies. Using the results of the cool storage analysis, the load profile with and without cool storage was analyzed by applying the existing rate structures to determine the potential savings to the customer from the installation of cool storage. In the final analysis step, the results of savings to the customer were used to identify potential market penetration of cool storage for each customer segment. Comparison studies of the economics between the three types of storage strategies indicate that partial storage systems have shorter payback times than the other two storage strategies; full storage has the longest payback. The total megawatt deferred due to cool storage for alternative programs offered by Florida Power and Light Company were also estimated by using the market penetration model. Figure 5 summarizes the total forecasted megawatt deferred in the year 2001 for six alternative programs: (1) nothing-base penetration with no programs, (2) information program, (3) performance guarantees-the ufility guarantees the system performance so that owners are willing to invest, (4) low interest loans-loans are offered at 2 percent lower than the market interest rate, (5) guaranteed payback--the utility provides a rebate so that any system with a payback of less than 7 years would be guaranteed a payback of only 3 years, and (6) rebates-a rebate of $\$ 100$ for each kilowatt deferred. Figure 5 clearly shows that the rebate program has the strongest effect on the penetration of the cool storage market. The breakdown of this rebate incentive program by building type is shown in Table 1. As seen from the table, large office buildings account for over 40 percent of the deferred capacity in the year 2001. This study clearly indicates that, for a strong penetration of the cool storage technology in the developed countries, incentives and rebates should be offered by utilities.

Since 1981, Texas electric utility companies have encouraged the installation of thermal storage systems in commercial buildings by offering a monetary incentive to qualified commercial customers and by applying special rate structures based on a TOU rate. (The on-peak period of this TOU is from noon to 8 p.m.) The Texas experience is a clear indication of the importance of the utilities' participation in accelerating penetration of this technology. In Dallas, for example, thermal cool storage installation in newlyconstructed commercial buildings in that city increased in 1982 and 1983 by 21 and $30 \%$, respectively. By $1984,38 \%$ of the new office buildings used thermal storages [23]. Thus, the rapid increase in two years $(81 \%$ increase in 1984) clearly indicates that there is a growing interest in thermal cool storage among customers in commercial sectors where there is active participation by utilities.

3.1.2. Developing Countries. A detailed preliminary study of the applicability and potential of cool storage technology in the Association of South-East $A^{\prime}$, ian Nations (ASEAN), which includes Indonesia, Malaysia, the Prilippines, Singapore, and Thailand, was carried out by Wyatt and de la Moriniere [8]. In this study, the emphasis was on indepth analyses of key parameters relevant to the feasibility of the cool storage technology; these parameters are utility load curves, load factors, rates, capital and operational costs, dependence on imported oil, lead time between planning and building of new capacity to accommodate the peak demand, and losses during transmission and distribution of the electricity. Since thermal storage is a load management strategy, the most important parameter investigated was the shape of the utility load curves. For potential use of thermal cool storage, a utility load curve must show a well-defined peak which coincides with the cooling load profile in commercial buildings, which then become possible candidates for thermal storage. 


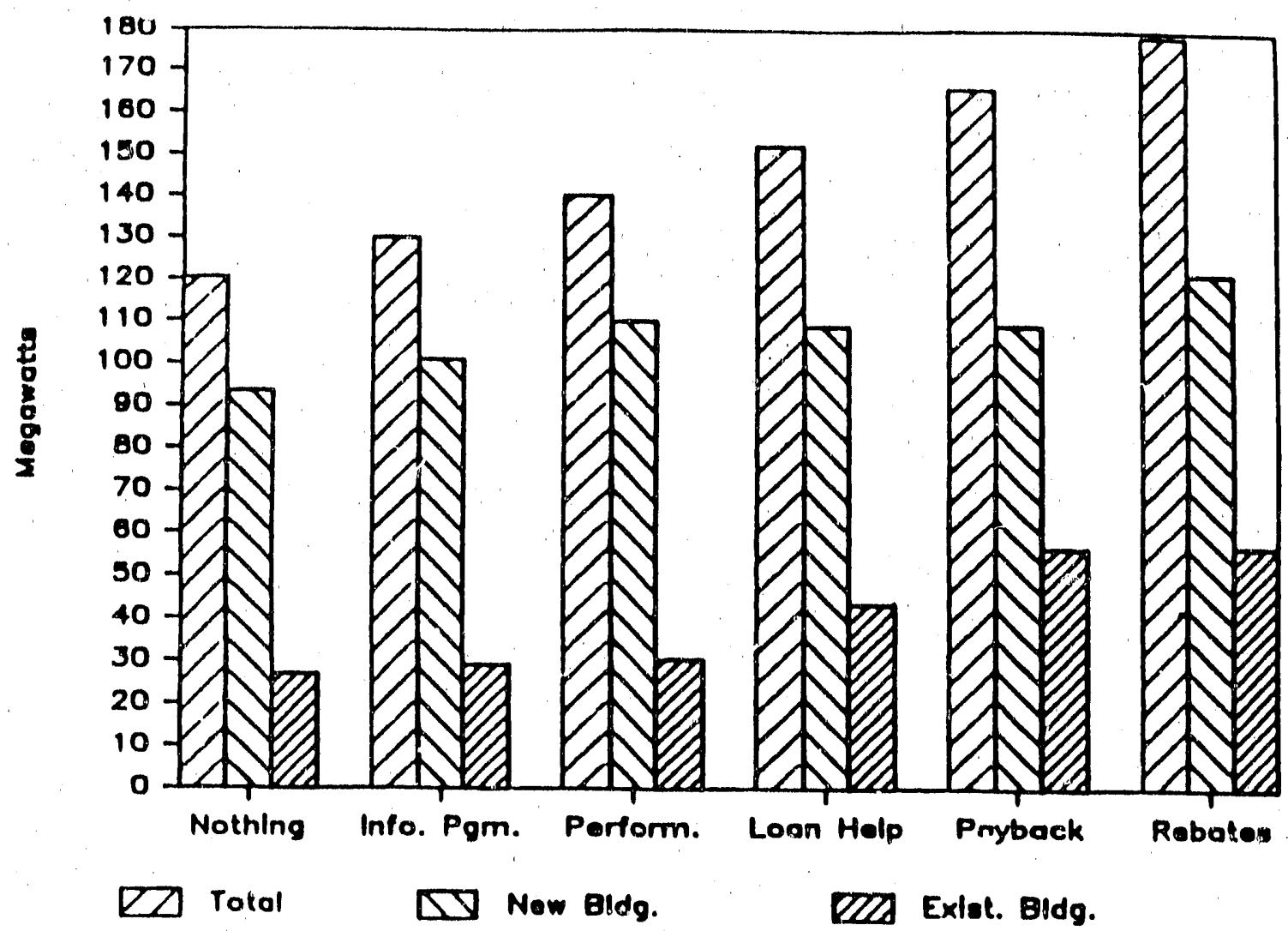

Figure 5. The Effect of Utility Incentive Programs on Summer Peak Megawatt Saving for Florida Power and Light Company in Year 2001. Nothing: base penetration; Info. Pgm: an information program that increases the market size by 4\%; Perform: performance guaranteed by utility; Load Help: low interest loan at $2 \%$ below the market; Payback: guaranteed 3 years payback; Rebates: a $\$ 100 / \mathrm{kW}$ deferred rebate.

For the initial assessment of the potential for storage, the utility load profiles for the ASEAN countries were plotted to see whether they fall within the required pattern. It was found that a peak existed f:om late morning to late afternoon, with a "plateau" during this period, for Malaysia (see Figure 6b). The demand curve for the Philippines showed a late morning and evening peak as shown in Figure 6c. In Thailand, the demand increased during the day and reached the peak value in the early evening (see Figure $6 d)$. The utility load curve for Indonesia, however, is found to be different from the other ASEAN nations; the utility faces an evening peak resulting from use of electricity in residences (see Figure 6a). The commercial and industrial sectors are very small, and, therefore, they do not contribute significantly to the demand.

The ASEAN countries have the same business hours in the commercial sector as in the United States (8 a.m. to 5 p.m.). The utilities peak demand period in Malaysia, the 

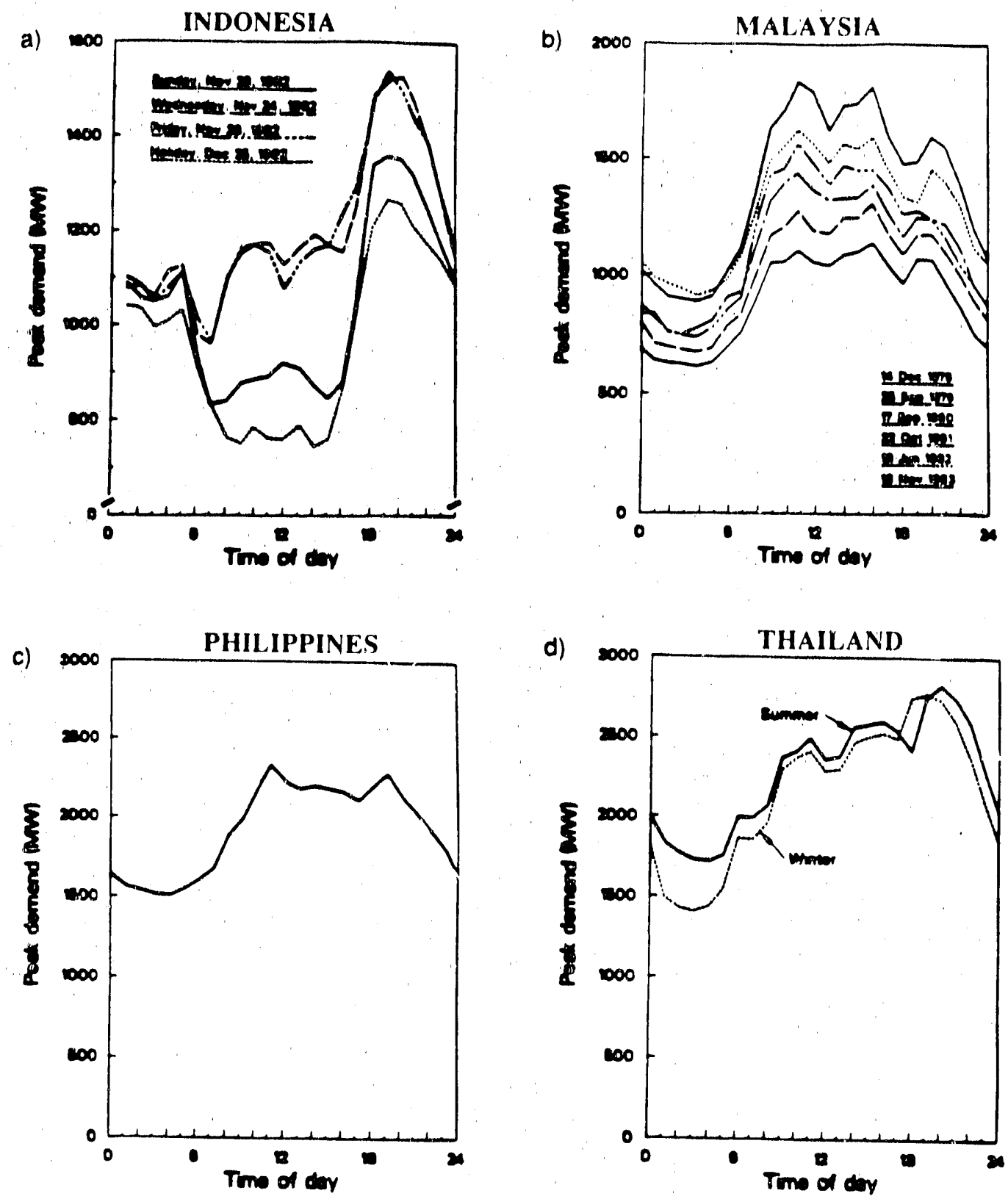

Figure 6. Typical Electricity Daily Load Profiles for ASEAN Countries. (a) Indonesia, (b) Malaysia, (c) Philippines, and (d) Thailand.

Philippines, (and Singapore, not shown in Figure 6) occurs during these business hours, suggesting that thermal cool storage may be feasible in these countries. On the other hand, in Thailand and Indonesia, the commercial cooling load does not contribute significantly to the peak demand; therefore, cool storage may not be as appropriate as in the other ASEAN countries at this time. 


\subsection{Applications for Commercial Cool Storage Systems}

Thermal storage is most economical in buildings where cooling demands significantly contribute to high demand charges or where there is a significant differential between day and night or TOU energy rates. Office bulldings are ideal for cool storage installations because they have short occupancy periods and, therefore, narrow cooling loads. Another application for cool storage systems occurs in an existing facility undergoing an expansion which requires additional capacity to the central chilled water system [24]. Instead of adding new chillers, the extra nighttime capacity of existing chillers can be used to charge a storage tank to serve the new floorspace.

Orie of the most interesting new uses of cool storage is in aircraft cabin cooling [25]. The Delta Airline cabin cooling project at O'Hare International Airport is the first known application of storage cooling to aircraft docked at airport gates. The system used is a full-storage ice system of 1000 ton-hours capacity. Delta Airlines plans to equip all major gates in its system with some form of fixed ground air-conditioning system. Fur example, in Dallas/Fort Worth International Airport, a partial ice storage system will be installed with continuously operating chillers in series with an ice bank of approximately 600 ton-hours capacity. In the United States, conventional ground cooling operation costs the airline industry over $\$ 100$ million per year in fuel cost alone. Therefore, it is expected that the other airlines will soon follow Delta Airlines in installing storage system for cabin cooling.

\section{ECONOMICS OF THERMAL ENERGY STORAGE}

Many factors affect the decision leading to installation of cooling storage for a building. One, and pertiaps the most important one, is the electricity cost consisting of demand charges $(\$ / \mathrm{kW})$ and the differential between the cost of electricity at peak hours and off-peak hours $(\$ / \mathrm{kWh})$. Under constant rates (no demand charge and no TOU rates), all hours are essentially on-peak. Thermal energy storage strategy helps the utility to shift its peak to off-peak. However, the customer does not benefit by shifting the peak demand to off-peak under constant rate structure. ${ }^{*}$

The savings in the cost of electricity could result from either decreasing the demand charges $(\$ / \mathrm{kW})$ or lowering the electricity cost $(\$ / \mathrm{kWh})$ by shifting the operation of chillers from peak to off-peak hours or both. Many utilities offer rate schedules w'sich include both demand and varying $\mathrm{kWh}$ charges. It is this rate schedule that makes thermal energy storage attractive (or not attractive) to the customer. Changes in the demand charges and TOU electricity rate would change the economic attractiveness of thermal energy storage. As an example, the electricity rate schedules in two neighboring utilities (San Diego Gas and Electric Company, SDG\&E, and Los Angeles Department of Water and Power, LADWP) are such that the annual savings due to thermal energy storage is twice as attractive in SDG\&E's service area than in LADWP's (cf. Figure 10).

\footnotetext{
- In developing countries, where the supply of electricity has not grown at the same rate as growth in demand, there are usually several hours of brown-out for part of the grid during peak hours. The lack of electricity during the peak hours in the commercial sector affects the comfort condition and hence productivity of the occupants. Therefore, installation of thermal energy storage would have the additional benefit of providing comfort under such conditions.
} 
The other parameters affecting the decision include existing equipment and operation of the building (base case), storage strategy, the cost and economics of the system compared to the base case (including rate of return, net present value, annual dollar savings, etc.), and the operational and control sophistication of the thermal energy storage.

Recently, Rosenfeld and de la Moriniere [5] studied the cost-effectiveness of commercial cool storage and developed a generalized framework for comparing partial and demand-limited thermal energy storage strategies. Three economic indicators-simple payback time (SPT), net present value (NPV), and cost of avoided peak power (CAPP) -were selected for comparative study.

To analyze the economics of thermal storage, a simplified cooling load, as shown in Figure 7, has been assumed to represent a typical base case commercial building load profile. In the base case, a chiller with capacity $L$ operates during occupied hours. However, for the partial storage, a chiller with a reduced capacity of $C(=0.375 L)$ operates coritinuously. In the case of demand-limited storage (in this example, the same as full storage), a chiller with the capacity of $0.53 \mathrm{~L}$ operates at all hours except during building peak hours ( 11 a.m. to 6 p.m. as shown in the figure).

The storage and chiller costs have been obtained from available sources. The cocts for various storage and chiller sizes are shown in Figures 8 and 9, respectively. On average, the chiller cost is about $\$ 340$ per ton with storage costs from $\$ 40$ to $\$ 100$ per ton. To calculate the annual dollar savings, an on-peak period of 6.5 hours and a cooling season of 6 months are assumed for the commercial building studied.

Based on these assumptions, the annual savings of shifting one $\mathrm{kW}$ from on-peak to off-peak are calculated and presented in Figure 10. Figure 10 shows the lines of constant an'ual savings on a graph of demand charges versus electricity differential charge between on-peak and off-peak periods. Electricity rate schedules for several utilities in the United States and some developing countries are also shown in Figure 10. For the developing countries, because of the lack of data, we have conservatively assumed that there is no differential rate structure, but demand charges are assumed. Therefore, the annual savings for these countries indicate the minimum saving potential of thermal energy storage.

The simple payback time is calculated using the annual savings and cost of storage and chiller and is summarized in Figure 11. As is seen, partial storage is far more economically attractive than demand-limited storage. For example, in Southern California Edison's (SCE) service area ( $\$ 50 / \mathrm{kW}$ savings per year), the payback periods for partial and demand-limited storages at a cost of $\$ 50 /$ ton-hour are estimated from Figure 11 to be approximately 2 and 5 years, respectively.

In some cases, partial storage could be even more attractive than the conventional systems; the savings due to downsizing the chiller pays for the cost of storage. As we will review in the following section, even though this may be the case with engineering calculations, the actual savings in some cases have been much lower than estimated ones. Arnong many reasons for this discrepancy, one could mention errors in the sizing of the system, failure in the operation, and inexperienced operators. Figure 12 shows the actual cost of 12 thermal energy storage installation in the United States; half of these installations are clustered around an incremental first cost of zero. 


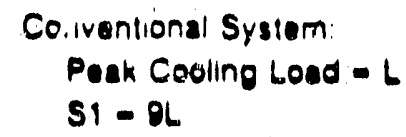

Partial Slorage

c- chilier capacily

$24 c-S 1 \rightarrow c-S 1 / 24$

-0375 L

$S$ - slorage sapacity

$S-(8+6) c-14 c$

$-14 C \rightarrow S-525 L$

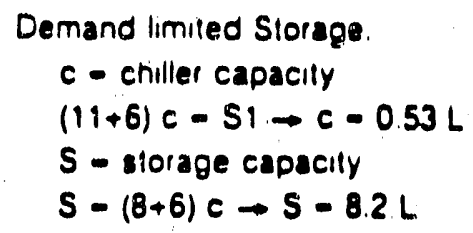

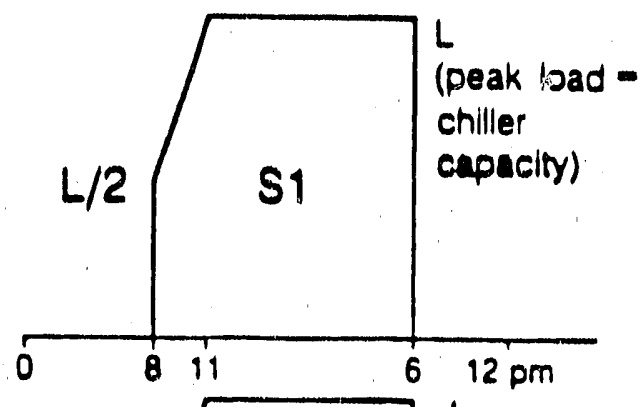
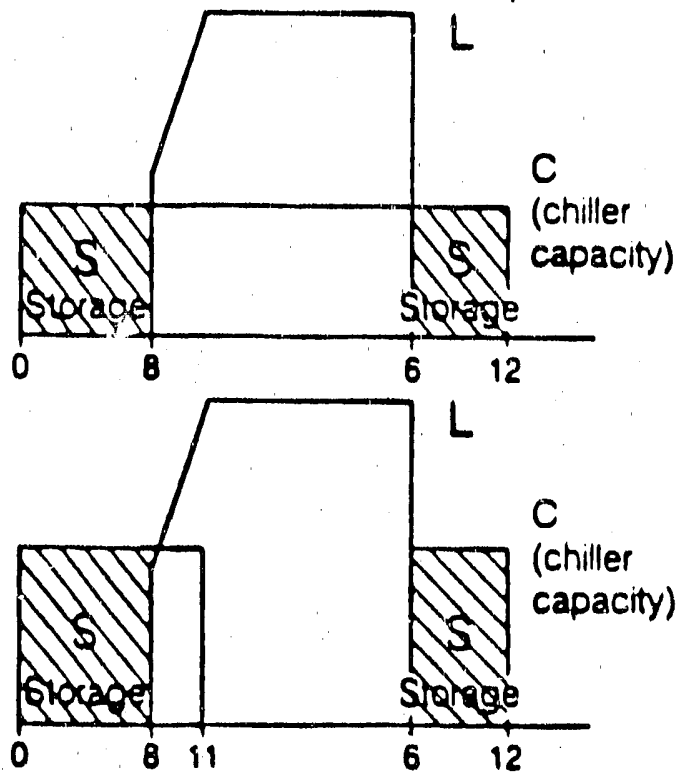

Figure 7. Calculation of the Capacities of Chiller and Storage According to the Load Profile. S1 is the daily cooling load, C the chiller capacity, and S the storage capacity.

\section{EXPERIENCE WITH THERMAL COOL STORAGE SYSTEMS}

Cool storage systems in commercial buildings are beneficial to both electric utilities and their customers. The penetration of cool storage systems has been slowed because of the lack of fleld performance data to compare with design expectations.

Field performance studies have been recently initiated by the Electric Power Research Institute (EPRI) [26] for (1) the assessment of the performance and operating experience of cool storage systems, (2) the identification of design problems, determination of possible corrective measures, and estimation of expcuted performance improvements, and (3) the determination of feasibility and cost-effectiveness of retrofitting to achieve performance improvements. For these purposes, five systems that were instrumented and monitored for at least one year by utilities in California, Illinois, Pennsylvania, and Rhode Island were evaluated. Four of the buildings had direct-expansion refrigeration ice storage systems operating in full storage mode and ranging in size from 150 to 2,000 ton-hours, and one had a 60,000 gallon chilled water system operated in partial storage mode. 


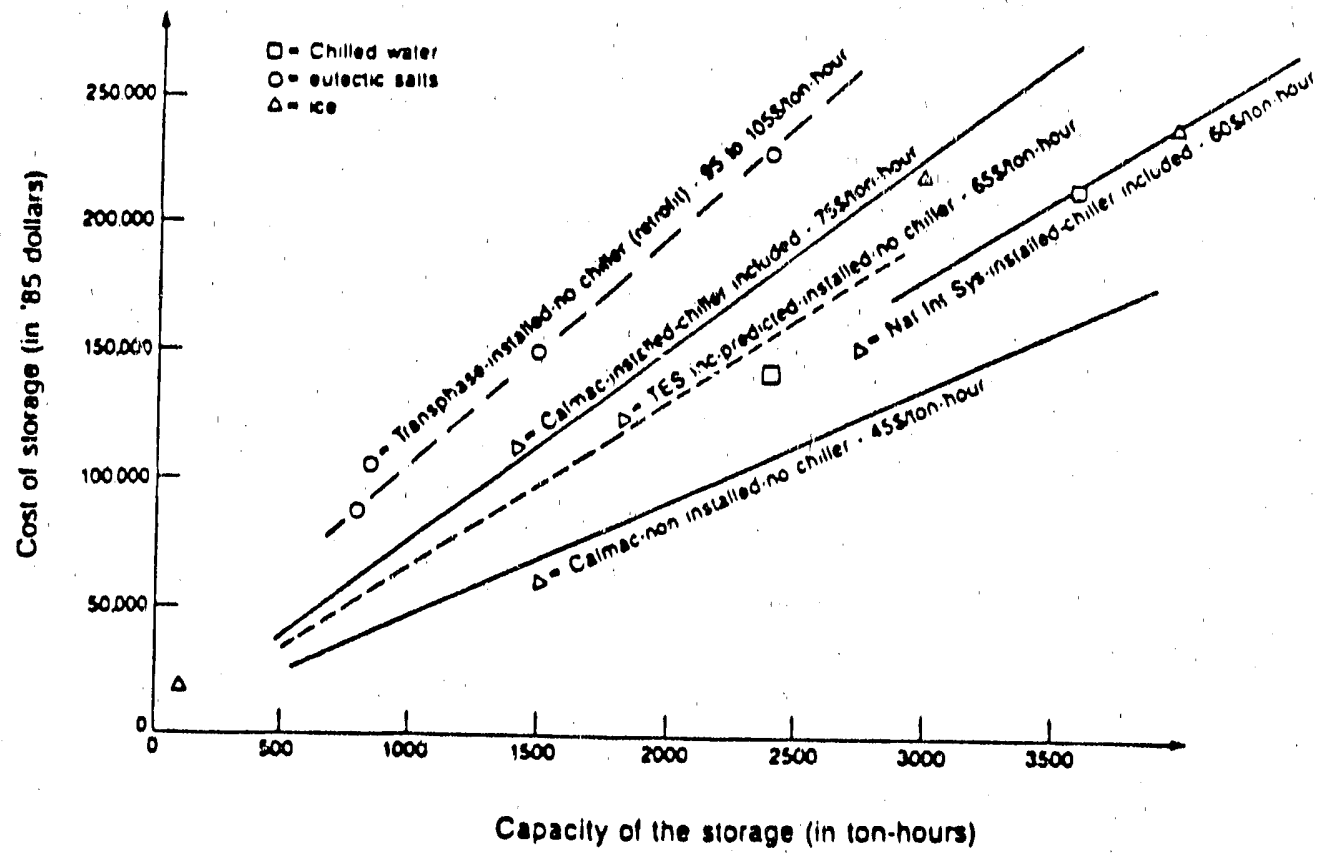

Figure 8. Installed Cost of Storage. Quoted by manufacturers (lines) and engineers who have installed cool storage (dots). Note that some data include the chiller, some not, some include installation, some not. [Source: Ref.5.]

The available field data were used to establish system performance as measured by the amount of reduction in on-peak demand and the ratio of electrical input to the delivered cooling effect in $\mathrm{kW} / \mathrm{ton}$. In addition, wherever possible, the corresponding measures were calculated for a conventional HVAC system.

In this study, Ayres, et. al [26] found that all of the systems suffered from technical and operational problems and classified them into four different categories:

(1) Information Availability: Lack of complete drawings, construction records, and HVAC design calculations.

(2) System Design: It was found that the systems designed by HVAC designers with little or no experience in field-erected refrigeration plants resulted in improper refrigerant line sizing, insufficient water flow through the unit to provide proper ice melting, etc.

(3) Equipment Maintenance and Operation: Most of the systems suffered from mechanical time clock failures, improper expansion valve and ice thickness control settings, and improper water treatment. In addition, all installations suffered from inadequate operator training.

(4) Monitoring System: It was also found that the monitoring sensors were improperly selected, located, maintained, and/or calibrated.

In spite of the above-mentioned problems, all of the systems were able to shift electric demands from on-peak to off- and mid-peak periods. However, they were 


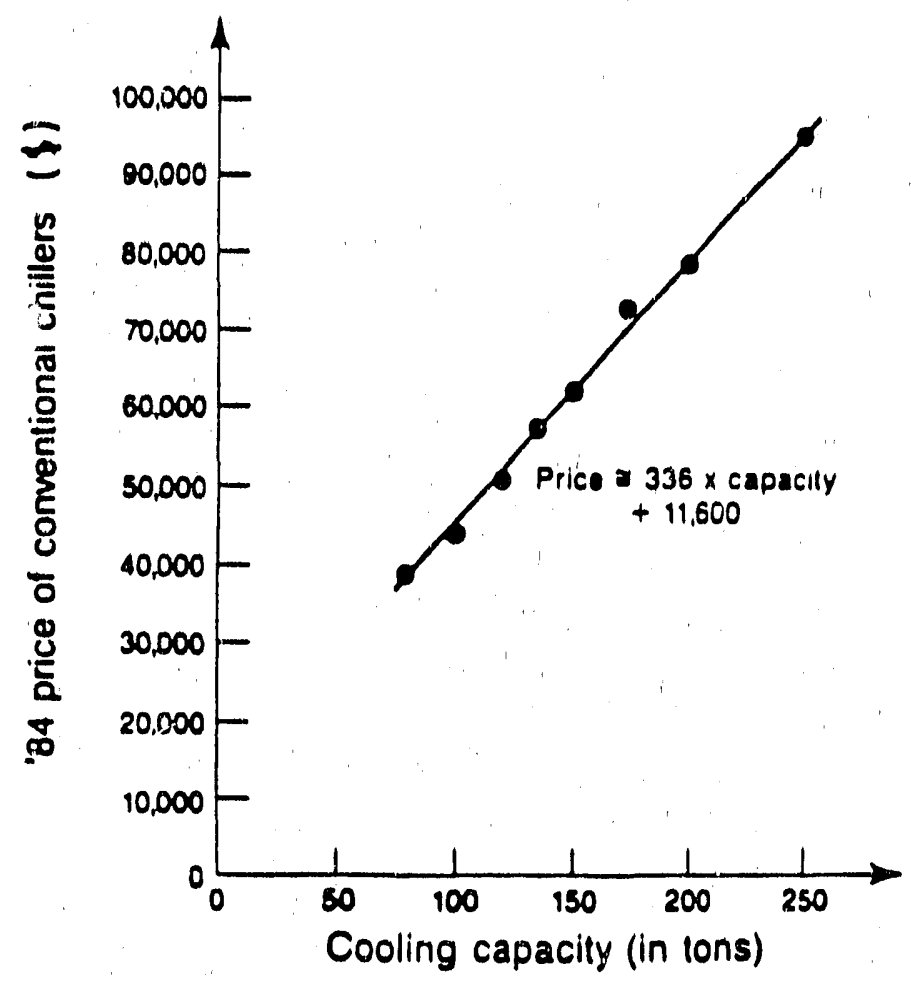

Figure 9. Installed Average Cost of Conventional Chillers (in 1984 \$). Data include profit. [Source: "Means Construction Cost Data 1980" with 25\% inflation from 1980 to 1984.]

occasionally activated during on-peak periods due to mechanical failures and operator errors. For ice systems, it was found that 10 to $20 \%$ of the total chilled water plant energy was consumed during on-peak periods; the energy consumed during mid-and off-peak periods ranged from 80 to $90 \%$. The performance of the ice systems was in the range of 1.7 to $2.2 \mathrm{~kW} / \mathrm{ton}$. (The performance of comparable conventional HVAC systems ranged from 1.15 to $1.57 \mathrm{~kW} /$ ton.) On the other hand, the performance of the chilled water system which operated in partial storage mode was found to vary between 1.15 to $1.78 \mathrm{kVV} /$ ton within the five-month testing period. The energy consumption of the chilled water system during on-peak periods was found to be $47 \%$ of the chilled water plant energy. This higher energy consumption during on-peak hours may be attributable to the size of the storage tank, which was designed to provide $30 \%$ of the summer design day peak cooling load due to the owner's economic decision to locate the tank in the available space below the garage floor. Therefore, the remaining load $(70 \%$ of the total cooling load) had to be met by the chiller during on-peak hours.

Similar perforrnance studies were also carried out by the Commonwealth Edison Company in Illinois [27]. Several ice storage system installation were separately evaluated by the utility at various sub-component levels. A comparison was also made between a storage system and a simulated conventional chiller in order to determine the benefits obtained by both the utility and the consumer. The energy consumption for the conventional system was determined by using hourly weather data for the given location and the chiller model. The installation evaluated was a combination of a full storage and demand-limited storage ice system located in Riverwoods, Illinois. Although the system 


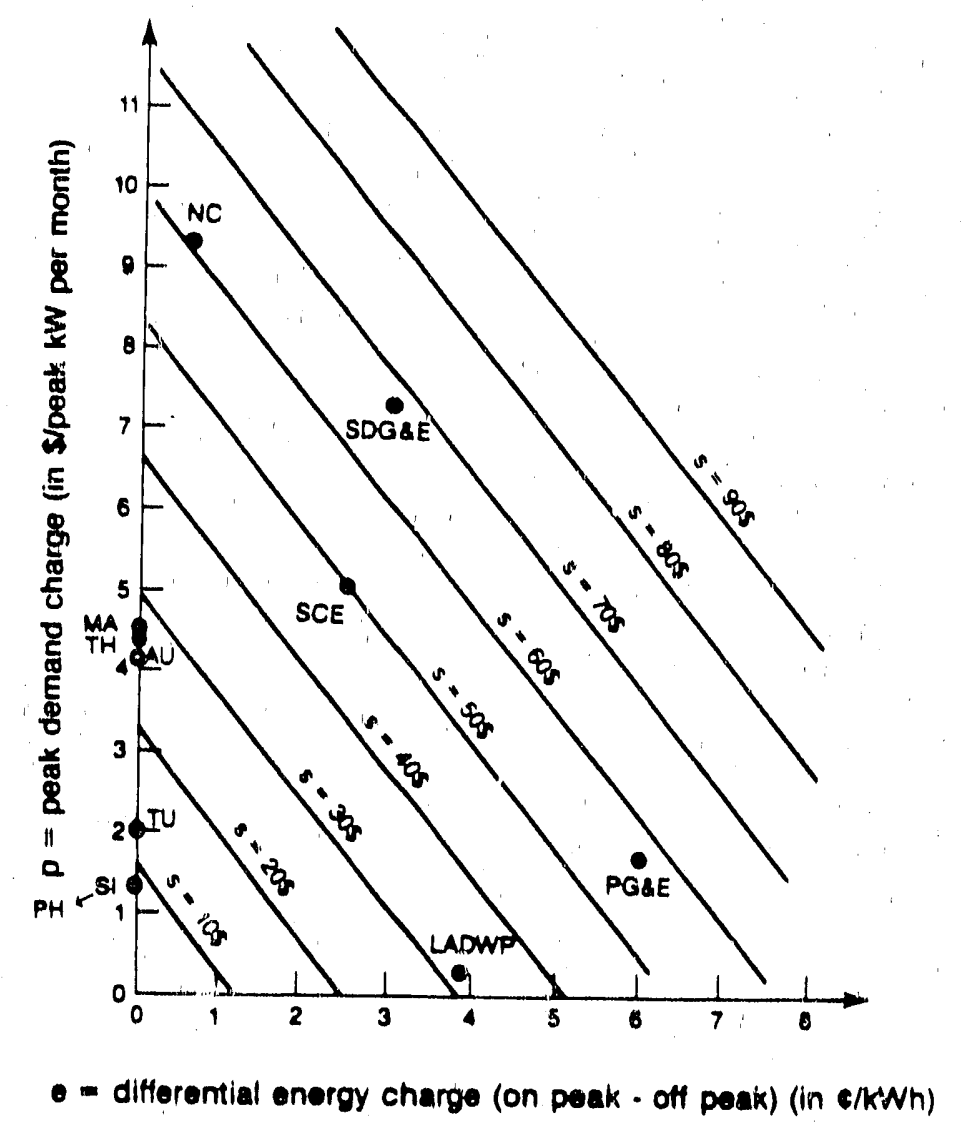

Figure 10. Annual Dollar Savings of Shifting $1 \mathrm{~kW}$. Savings are estimated for shifting $1 \mathrm{~kW}$ for 6.5 hours from on-peak to off-peak for many utilities, characterized by their monthly demand charge " $p$ " and their energy on-peak off-peak differential cost "e". AU: Austin Utility; LADWP: Los Angeles Department of Water and Power; MA: Malaysia; NC: North Carolina; PG\&E: Pacific Gas and Electric; PH: Phillppines; SCE: Southern California Edison; SDG\&E: San Diego Gas and Electric; SI: Singapore; TH: Thailand; TU: Turkey [28].

has been in service since 1982, the study reported the system performance for the 1984 and 1985 cooling seasons only. The performance of the system was measured by analyzing the peak billing demands. The peak periods were defined as the hours between 9 a.m. and 10 p.m., Monday through Friday. Demand charges were applied only to demand registered during on-peak periods. All metering was done with a magnetic tape demand recorder at 15-minute intervals. The bullding was occupied between 9 a.m. and 4 p.m. The ice-making cycle was scheduled from 6 p.m. to 9 a.m. and the chilled water pumps were operated from 6 a.m. to $6 \mathrm{p} . \mathrm{m}$.. At the end of the performance monitoring period, it was concluded that the ice storage system is an effective load management strategy from a utility standpoint. The load factor (the average to peak demand ratio) of the building was found to be significantly improved while eliminating approximately $170 \mathrm{~kW}$ of summer peak demand. In the first two years of operation, many on-peak demands were found to be created by an unreliable mechanical time clock. It was suggested that the operation of the system should be assigned to an 


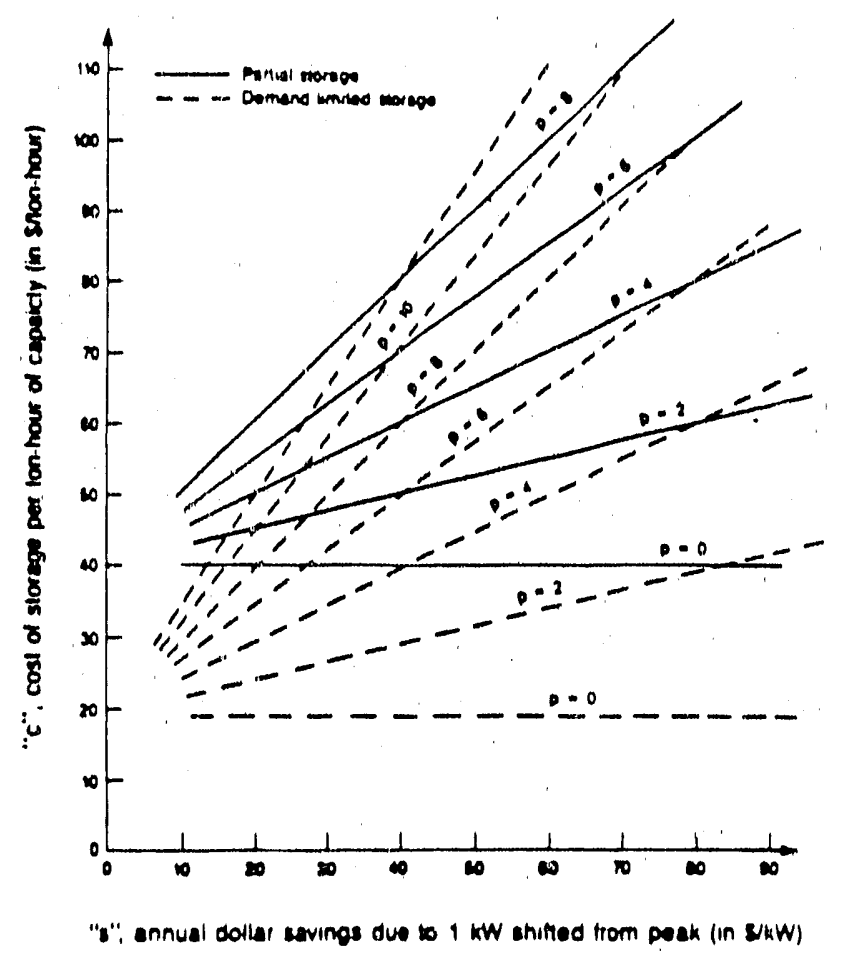

Figure 11. Payback Time. Estimated simple payback time for partial (solid lines) and demand-limited (dashed lines) strategies.

energy management system or an electronic time clock with battery back-up.

Texas Utilities Electric Company has also been actively involved in promoting thermal cool storage as a load management strategy. A recent survey indicates that there are twenty projects currently using or constructing thermal storage systerns [23]. The survey also shows that, in contrast to experience in other states, most of the systems in Texas use chilled water as the storage medium. Four installations in Dallas area were studied in detall. One of the installations studied was the first major office building to use thermal storage for demand shifting. Its thermal storage system was designed in 1981 without any' encouragement from the utility. The system was designed around four 375,000 gallon concrete tanks that use a flexible diaphragm to separate supply and return water. Two of the storage tanks are convertible to hot water storage during the heating season. The cooling/heating system serves a 50-story $1,500,000 \mathrm{ft}^{2}$ office bullding in downtown Dallas. During initial start-up of the system, several problems developed regarding the tank liners and the diaphragm movement within the tanks. The original rubber liners were replaced in 1983 with a spray-on/trowel-on waterproofing agent that subsequently stopped all water leaks. In 1984, the energy cost reduction of the building was estimated to be $17 \%$ due to the use of thermal storage. Half of the savings accrued from lower demand charges during the air-conditioning season; the remainder of the savings was $\mathrm{kWh}$ savings during the heating season.

\section{CONCLUDING REMARKS}

Thermal cool storage is increasingly belng used in developed countries because of current utility rate structures and the additional incentives offered by utility companies to 


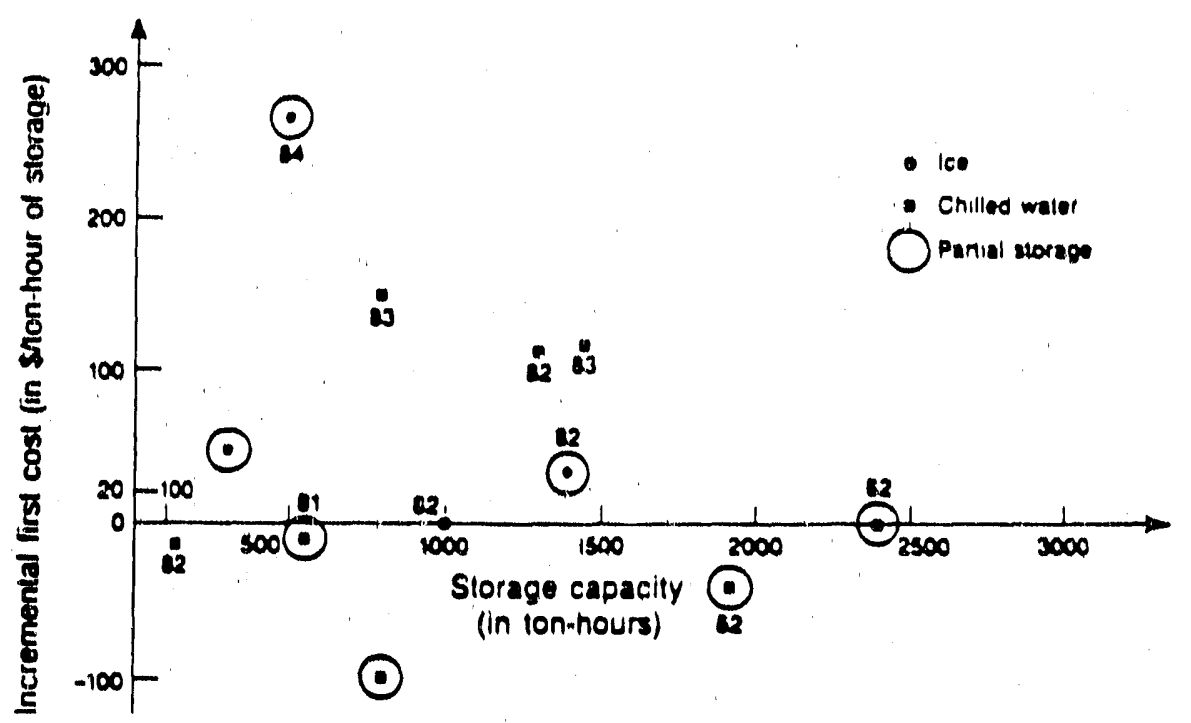

Figure 12. Incremental First Cost (Installing Storage Instead of a Conventional Chiller) from Case-Histories in Real Buildings. The costs are not representative of the average first costs faced by owners when installing a cool storage system, but they do show that compensating the first cost of the storage only by the savings from downsizing the chiller is already possible in the field. Note that more than half of the data points are clustered around zero initial differential cost.

accelerate the penetration of this technology. These incentives include (1) application of a different rate structure so that customers who do not use storage systems to shift the load to off-peak hours are penalized by higher demand and $\mathrm{kWh}$ charges, and/or (2) offering partial monetary refunds to the customer who installs a storage system. The number of cool storage installations in the United States has been doubling each year since 1985; about 100 installations in 1985, 200 in 1986, and an estimated 400 installations in 1987 [17]. The penetration of the technology has been higher in regions where a significant day- and night-time differential exists in the price of eleciricity. Most thermal storage installations are chilled water and ice storage systems. However, more installathons are using eutectic storage with the recent decrease in the price of these systems.

Recently, an international thermal storage advisory committee (ITSAC) has been established to facilitate the exchange of information between users of this technology. The objectives of ITSAC are to (1) enhance the development of the technology, (2) provide a forum for techinology evaluation, (3) seive as an information clearinghouse, (4) disseminate up-to-aate information, and (5) encourage widespread application.

As discussed above, the incentives offered by the utility compariles play an important role in accelerating the penetration rate. ITSAC has compiled incentives currently offered by the utility companies in the United States (see Appendix 1). These incentives ranges from $\$ 60$ to $\$ 42.5$ rebate per $\mathrm{kW}$ shifted to off-peak periods.

Even though utility companies offer economic incentives for the installation of the cool storage systems, there are still, however, some practical difficulties in the use of the technology. Thes a difficultles include (1) errors in the sizing of the systern which results 
In longer payback time, (2) failure in the operation of the system due to mechanical malfunctioning of equipment and control systems, and (3) Inexperienced operators who could cause inefficient operation of the system; in theory, it would take only one operational fallure per month to lose all the benefits of cool storage due to the increase in monthly demand. Therefore, it is vital for users of cool storage technology to exchange information regarding the difficulties and problems encountered in design and operation of the system.

The Building Energy Data Group at Lawrence Berkeley Laboratory has compiled cool storage performance data for actual installations. A list of commercial cool storage installations in the United States as well as in other developed and developing countries is provided in Apperidix 2. Some of these cool storage installations have been analyzed and reported elsewhere [9]. Analysis of the performance of the actual installations has shown that many of the earller difficulties have been resolved and cool storage is becoming more economical and operationally attractive as technology develops further.

\section{ACKNOWLEDGEMENT}

This work was supported by the Assistant Secretary for Conservation and Renewable Energy, Offlce of Bullding and Community Systems, Building Systems Division of the U.S. Departmert of Energy, and by the U.S. Agency for International Development, under DOE Contract No. DE.-AC03-76SF00098.

We would also like to acknowledge the editorial support provided by Karen $\mathrm{H}$. Olson of Lawrence Berkeley Laboratory.

\section{REFERENCES}

(1) 1981 Survey of Utility Load Management, Conservation, and Solar End-Use Projects, 2 Volumes, Electric Power Research Institute Report, EPRI EM-2649, June 1983.

(2) Proceedings: EPRI Load Research Symposium, Electric Power Research Institute Report, EPRI EA-3389, Febrliary 1984.

(3) Proceedings: International Load Management Conference, Electric Power Research Institute Report, EPRI EM-4643, June 1986.

(4) Shlachtman, P.J. and Parker, J.H., "Peak Load Energy Conservation," In Energy Conservation Management/Education, Alternative Energy Sources IV, edited by T.N. Veziroglu, Vol. 7, pp. 19-29, Ann Arbor Science Publishers, Ann Arbor, Michigan, 1982.

(5) Rosenfeld, A. and de la Moriniere, O., "The High Cost-Effectiveness of Cool Storage in New Commercial Buildings," in ASHRAE Transactions, Vol. 91, Part 2, pp. 818-832, 1985.

(6) Engineering Interface Lirnited, "Commercial Cool Storage Presentation Material, Vol. 1, Seminar Handbook; Vol. 2, Slide Package," Electric Power Research Institute Report, EPRI EM-4405, February 1986. 
(7) Tejl, D.S., "Thermal Storage Strategles for Energy Cost Reduction," prepared for Public Technology Inc., January 1986.

(8) Wyatt, E. and de la Moriniere, O., "The Feasibility of Commercial Building Thermal Energy Storage in ASEAN Countries," Lawrence Berkeley Laboratory Report, December 1986 (Draft).

(9) Plette, M.A., Wyatt, E., and Harris, J., "Technology Assessment: Thermal Cool Storage in Commerclal Bulldings," Lawrence Berkeley Laboratory Report, LBL24852, January 1988.

(10) Wilden, M.W. and Truman, C.R., "Evaluation of Stratlfied Chilled-Water Storage Techniques," Volumes 1 and 2. Electric Power Research Institute Report, EPRI EM-4352, December 1985.

(11) 1987 ASHRAE Handbook: Heating, Ventilating, and Air-Conditioning Systems and Applications, Chapter 46, American Soclety of Heating, Refrigerating and AirConditioning Engineers, Inc., Atlanta, Georgia, 1987.

(12) Pacific Gas Electric Company, "Thermal Energy Storage for Cooling," Seminar Notes, San Francisco, Californla, May 1985.

(13) EPRl, "Commercial Cool Storage Design Guide," Elrctric Power Research Institute Report, EPRI EM-3981, May 1985 (also published by Hemisphere Publishing Corporation, New York, 1987).

(14) Ott, V.J., "Thermal Storage Air Conditioning with Clathrates and Direct Contact Heat Transfer," in Proceedings: International Load Management Conference, pp. 47.1-47.9, Electric Power Research Institute Report, EPRI EM-4643, June 1986.

(15) Tomlinson, J.J., "Clathrates and Conjugating Binaries: New Materials for Thermal Storage," ASHRAE Transactions, Vol. 91, Part 2, pp. 1931-1937, 1985.

(16) Warren, M.L., "Impact of Operation and Control Strategy on the Performance of a Thermal Storage System," Lawrence Berkeley Laboratory Report, LBL-20180, 1985.

(17) McCracken, C.D., Wenland, R., Knebel, D., Holness, G., and Geistert, D., "A Forum on Thermal Storage," ASHRAE Journal, pp. 20-27, May 1987.

(18) "Characteristics of Commercial Sector Buildings and Their Energy Use and Demand," Electric Power Research Institute Report for the project RP1201-26, April 1984.

(19) Asian Development Bank, "Asian Electric Power Utilities Data Book," 1985.

(20) Lann, R:B., et al., "The COMMEND Planning System: National and Regional Data and Analysis," Electric Power Research Institute Report, EPRI EM- 4486, April 1986.

(21) International Thermal Storage Advisory Council, "ITSAC Technical Bulletin," March 1987.

(22) Zeidler, P.C., "Estimating the Market Penetration of Cool Storage at Florida Power and Light," in Proceedings: International Load Management Conference, pp. 22.122.12, Electric Power Research Institute Report, EPRI EM-4643, June 1986.

(23) Knipp, R. "Marketing Thermal Storage," In Proceedings: International Load Management Conference, pp. 21.1-21.33, Electric Power Research Institute 
Report, EPRI EM-4643, June 1986.

(24) Tambyln, R.T., "Chilled Water Storage Goes to College," ASHRAE Journal, pp. 39-44, July 1987.

(25) Hersh, H.N., "Current Trends in Commercial Cool "Storage," Electric Power Research Institute Report, EPRI EM-4125, July 1985.

(26) Ayres, J.M., Sowell, E.F., and Lou, H., "Performance of Commercial Cool Storage Systems; Vol. 1: Early Case Histories, Vol. 2: Cipher Data Products Ice Storage System Improvements," Electric Power Research Institute Report, EPRI EM-4044, June 1985.

(27) NcNeil, W.P., "Operating Experience With an Ice Storage System: A Case History," in Proceedings: International Load Management Conference, pp. 20.1-20.20, Electric Power Research Institute Report, EPRI EM-4643, June 1986.

(28) Sirin, G. Energy Statistics, Fourth Energy Congress of Turkey, Izmir, Turkey, 1986, (in Turkish). 
Appendix 1. Incentives Offered by U.S. Utilities

\begin{tabular}{|c|c|c|c|c|}
\hline Utility & & \multicolumn{3}{|c|}{$\begin{array}{l}\text { Inducement Per KW } \\
\text { of Load Shift }\end{array}$} \\
\hline Southern California Edison & & \multicolumn{3}{|c|}{$\begin{array}{c}\$ 200 \\
\text { F.S. }=\text { Match to 55,000 }\end{array}$} \\
\hline \multirow[t]{2}{*}{ San Diego Gas \& Elec. Co. } & RATE & $0-200 \mathrm{KW}$ & $201-1200$ TON & $1200 \mathrm{KW}$ \\
\hline & $\begin{array}{l}\text { TOU } \\
\text { Flat }\end{array}$ & $\begin{array}{c}\$ 250 \\
\$ 350 \\
0-200 \text { TON }\end{array}$ & $\begin{array}{c}\$ 225 \\
\$ 325 \\
201-1200 \text { TON }\end{array}$ & $\begin{array}{c}\$ 200 \\
\text { N/A } \\
1200 \text { TON }\end{array}$ \\
\hline New Construction & Both & $\$ 350$ per TON & $\$ 225$ per TON & $\$ 200$ per T JN \\
\hline TU Elec. Co. & & \multicolumn{3}{|c|}{$\begin{array}{l}\$ 350-\text { first } 200 \mathrm{~kW} \text { plus } \\
\$ 250-\text { next } 300 \mathrm{~kW} \text { plus } \\
\$ 200-\text { next } 500 \mathrm{~kW} \text { plus } \\
\$ 125-\text { all } \mathrm{kW} \text { over } 1000\end{array}$} \\
\hline Pacific Gas \& Elec. Co. & & \multicolumn{3}{|c|}{$\$ 200$} \\
\hline Arizona Public Service Co. & & \multicolumn{3}{|c|}{$\begin{array}{c}\$ 250 \text { - first kW plus } \\
\$ 115 \text { - all kW over } 500\end{array}$} \\
\hline $\begin{array}{l}\text { City of Austin, TX } \\
\text { Elec. Utility }\end{array}$ & & \multicolumn{3}{|c|}{$\begin{array}{c}\text { Variable - } 3 \text { year payback } \\
\text { up to } \$ 300 \text { per } \mathrm{kW}\end{array}$} \\
\hline City of Palo Alto, CA & & \multicolumn{3}{|c|}{$\begin{array}{c}\$ 350 \text { New Construction } \\
\$ 425 \text { Retrofit }\end{array}$} \\
\hline Public Service Elec. \& Gas & & \multicolumn{3}{|c|}{$\begin{array}{l}\$ 250 \text { - first } 500 \mathrm{~kW} \text { plus } \\
\$ 125 \text { - all kW over } 500\end{array}$} \\
\hline Salt River Project & & \multicolumn{3}{|c|}{$\begin{array}{l}\$ 250 \text { - first } 300 \mathrm{~kW} \text { plus } \\
\$ 115 \text { - next } 200 \mathrm{~kW}\end{array}$} \\
\hline Boston Edison & & \multicolumn{3}{|c|}{$\$ 200$} \\
\hline Long Island Lighting Co. & & \multicolumn{3}{|c|}{$\$ 300$} \\
\hline Los Angeles Dept. of Water & & \multicolumn{3}{|c|}{$\$ 250$} \\
\hline
\end{tabular}

No Maximum

No Maximum

No Maximı'm

$\$ 250,000$

No Maximum

$500 \mathrm{~kW}-\$ 98,000$

No Maximum

$\$ 50,000$

$40 \%$ of Cost or $\$ 150,000$ per

Building

Sacramento Municipal

$\$ 250$

Utility District

F.S. = Limited Number

$\$ 200$

$\$ 200$

El Paso Electric Co.

(or acceptable payback)

Wisconsin Elec. Power Co

Pennsylvania Electric Co. $\$ 200$ or $5 y$ r No-Interest Loans up to $\$ 750$ per $\mathrm{kW}$

F.S. = Match to $\$ 5,000$

No Maximum

New England Electric

$\$ 250$

$\$ 160$

Utilities Depi.

City of Denton, TX

$\$ 350$ - first $200 \mathrm{~kW}$

$\$ 250$ - next 200-500 kW

$\$ 200$ - over $500 \mathrm{~kW}$

Consolidated Edison Co.

$\$ 500$

$\$ 50,000$

No Maximum

No Maximum

No Maximum

No Maximum

No Maximum

No Maximum

Not to exceed $50 \%$ installed cost (portion of central

Manhattan only)

Jersey Central

$\$ 250$ - first $500 \mathrm{~kW}$

$\$ 200,000$ 
Power \& Light Co.

Northern States Power

Riverside Public Utilities

Anaheim Public Utilities

$$
\begin{gathered}
\$ 125 \text { - over } 500 \mathrm{~kW} \\
\$ 175 \\
\$ 200
\end{gathered}
$$

F.S. $=$ Match to $\$ 5,000$

$\$ 60$

$F . S .=$ Up to $\$ 5,000$
No Maximum

No Maximum

$\$ 50,000$

Key: F.S. $=$ Feasibility Study 


\section{BUIL.DINGS WITH COOL STORAGE SYSTEMS}

The following 321 buildings have cold storage systems. Buildings listed with an asterisk (*) are reported to have some submetering or an energy management systems that may provide some cooling systern data.

INFORMATION SOURCE CODES:

AN - Argonne National Lab/EPRI Survey

AS - ASHRAE Survey

CN - BECA-CN

E . List from Engineering Interface (March 1987)

EP - EPRI Metering

1 - ITSAC (and month/ year)

JD - Jacksonville Elec. Demo, maybe monitored

P - Pacific Gas and Electric Metering

SD - San Diego Gas \& Elec. Monitoring

SM - Sacramento Municipal Util. District Monitoring

TVA - Tenn. Valley Authority Monitoring
STORAGE TYPE SOURCE CODE:

CW - Chilled Water

C/HW - Chilled and Hot Water

ES - Eutectic System

IC - Ice system

$\mathrm{IC} / \mathrm{HW}$ - ice and Hot Water

u - unknown

SUMMARY OF COOL STORAGE INSTALLATIONS

\begin{tabular}{|l|cc|c|}
\hline Medium Type & U.S. & International & Total \\
\hline Chilled Water & 119 & 44 & 163 \\
(W/heat storage ${ }^{2}$ ) & $(37)$ & $(13)$ & $(50)$ \\
Ice & 130 & 7 & 137 \\
(w/heat storage ${ }^{2}$ ) & $(8)$ & & $(8)$ \\
Eutectic Salts $^{3}$ & 9 & - & 9 \\
Other/Unknown & 11 & 1 & 12 \\
\hline Total & 269 & 52 & 32. \\
\hline
\end{tabular}

1. 14 systems have or will be submetered

2. as a subset of chilled water and ice systems

3. 38 systems have or will be submetered 
UNITED STATES BUILDINGS

\begin{tabular}{|c|c|c|c|c|c|}
\hline TYPE & BUILDING & LOCATION & $\begin{array}{l}\text { AREA } \\
\left(\mathrm{ktt}^{2}\right)\end{array}$ & $\begin{array}{l}\text { SIZE } \\
\text { (k|b|kgal) }\end{array}$ & SOURCE \\
\hline $\begin{array}{l}\text { IC } \\
\text { CW } \\
\text { IC }\end{array}$ & $\begin{array}{l}\text { "Alabama Power Co. } \\
\text { Southern Co. Services } \\
\text { County school }\end{array}$ & $\begin{array}{l}\text { ALABAMA } \\
\text { Birmingham } \\
\text { Birmingham } \\
\text { Lower }\end{array}$ & $\begin{array}{r}1200 \\
870 \\
112\end{array}$ & 1000 & $\begin{array}{l}\text { AS,AN,I } \\
\text { AN } \\
\text { AN }\end{array}$ \\
\hline & & ARIZONA & & & \\
\hline IC & concrete company & Yuma & 7 & & \\
\hline $\begin{array}{l}\text { IC } \\
\text { IC }\end{array}$ & $\begin{array}{l}\text { "Little Theatre } \\
\text { "Arizona Public Service Cntr }\end{array}$ & Phoenix & $r$ & & 1 \\
\hline IC & "Central Library & Phoenix & 25.6 & & 1 \\
\hline IC & Fire Station \#21 & Phoenix & 4.9 & & \\
\hline IC & Fire Academy & Phoenix & 12 & & \\
\hline IC & Fire Support bullding & Phoenix & 13 & & \\
\hline IC & Maryvale Police Briefing Stn. & Phoenix & 8 & & \\
\hline IC & Pueblo Grande Museum & Phoenix & 20.5 & & \\
\hline IC & LEAP \#3 & Phoenix & 4 & & \\
\hline IC & Fleld Engineering & Phoenix & 3.5 & & \\
\hline IC & Giffen-Trane Service & Phoenix & 10 & 13.5 & AS \\
\hline IC & Baptist Church & Phoenix & & & \\
\hline $\mathrm{CW}$ & City Police Department & Phoenix & 147 & & \\
\hline$C W$ & Police Academy & Phoenix & 23.4 & & \\
\hline CW & "Municipal Bldg, Police Co. & Phoenix & 144 & & \\
\hline CW & Plaza Municipal & Phoenix & 34.4 & & \\
\hline CW & City Art Museum & Phoenix & 17.4 & & \\
\hline $\mathrm{CW}$ & Adult Cntr & Phoenix & 13.3 & & \\
\hline $\mathrm{CW}$ & Century Library & Phoenix & 6.5 & & \\
\hline$u$ & Abbott-Ross Labs & Casa Grande & & & \\
\hline $\mathrm{C} / \mathrm{HW}$ & IBM General Products Div. & Tucson & 2400 & 5100 & AS \\
\hline \multirow[t]{2}{*}{$\mathrm{C} / \mathrm{HW}$} & IBM Central Plant Bldg & Tucson & 25 & 2700 & AS \\
\hline & & CALIF. (CA) & & & \\
\hline IC & 100 Spear Street & San Francisco & 220 & & AN \\
\hline IC & "Sacramento Towers & San Francisco & 265 & & AN,P \\
\hline IC & ${ }^{*}$ Pacific Bell & San Rarnon & 1800 & & AN,P \\
\hline IC & "Bank of America & Livermore & 18.8 & & $P$ \\
\hline$u$ & "Graduate Theological Union & Berkeley & & & $\mathrm{P}$ \\
\hline $\mathrm{CW}$ & "Hewlett-Packard & Sunnyvale & & 520 & $1(9 / 86)$ \\
\hline IC & Gold Bldg (55 S. Mkt St) & San Jose & & & \\
\hline CW? & Alza Co. & Palo Alto & & & \\
\hline CW? & Ford Aerospace & Palo Alto & & & \\
\hline CW? & Kodak & Palo Alto & & & \\
\hline CW? & IBM & Palo Alto & & & \\
\hline CW & Stanford Univ. & Palo Alto & central & 4000 & \\
\hline IC & "SRI International & Menlo Park & central & & $\mathrm{P}$ \\
\hline IC & Wells Fargo Mortgage & Santa Rosa & 110 & & $C N$ \\
\hline IC & "Pacific Bell & Rohnert Park & 80 & & P,AN \\
\hline CW & `Pacific Bell & Chico & 20 & & P,AN \\
\hline$C W$ & "Calif. Farm Bureau Federtn. & Sacramento & 35 & & $S M, C N$ \\
\hline $\mathrm{CW}$ & Department of Justice Bldg. & Sacramento & 410 & & $\mathrm{CN}$ \\
\hline CW & State Bldg. Site 3 & Sacramento & 237 & 5 & AN,AS \\
\hline IC & State Site 3 & Sacramento & 225 & 50 & AS \\
\hline
\end{tabular}




\begin{tabular}{|c|c|}
\hline IC & Pac Bell Switching Office \\
\hline IC & James Madison/Monroe Elementary \\
\hline $\begin{array}{l}\mathrm{C} / \mathrm{HW} \\
\mathrm{IC}\end{array}$ & $\begin{array}{l}\text { SCE San Joaquin Custumier Serv. } \\
\text { mexican food factory }\end{array}$ \\
\hline IC & supermarket \\
\hline ES & Kings Co. Government Cntr \\
\hline$u$ & "Tenneco West \\
\hline $\mathrm{C} / \mathrm{HW}$ & U.S. Air Force \\
\hline & Jesse Ranch project \\
\hline ES & Hughes, SB Research Cntr \\
\hline CW & Thousand Oaks Library \\
\hline IC & Whittaker Corp (Taker Systms Div) \\
\hline CW & Manufacturers Life Insur. \\
\hline CW & Wells Fargo Bank \\
\hline u & Los Angeles World Trade Cntr \\
\hline CW & •Prudential Airport Tower \\
\hline $\mathrm{CW}$ & Kllroy Airport Cntr \\
\hline IC & insurance company \\
\hline CW & 1150 E 4th Street \\
\hline ES & St. Mary Med. Cntr \\
\hline ES & St. Bernardine Med. Cntr \\
\hline$u$ & Riverside City Hall \\
\hline IC & Union Oil--Hartley Resrch. Cntr \\
\hline IC & “Cipher Data Products \\
\hline IC & “Griffin Tower \\
\hline ES & Hughes Aircraft \\
\hline IC & Pacific Bell office \\
\hline ES & Allergan Pharmaceuticals \\
\hline ES & Leisure World/Rossmoor Towers \\
\hline ES & Orange Coast College Admin \\
\hline IC & office building \& bank \\
\hline u & unknown \\
\hline IC & *Anderson's Rest. \& Moiel \\
\hline IC & Cathedral-of-the-Valley \& School \\
\hline IC & office park project \\
\hline IC & Hotel Del Coronado \\
\hline $\mathrm{CW}$ & TRW Rancino office \\
\hline IC & Park North ifed Cntr \\
\hline ES & Mercy Hospital \\
\hline IC & NCR Corporation \\
\hline IC & "Four Winds Enterprises \\
\hline IC & "IRT Corporation \\
\hline IC & "Kearny Electric \\
\hline IC & "credit union \\
\hline IC & "SDGE Beach Cities Cntr \\
\hline IC & SD State Univ Med. Cntr \\
\hline IC & Bank of America Plaza \\
\hline IC & Security Pacific Bank Plaza \\
\hline IC & Central Savings Tower \\
\hline IC & AMCC \\
\hline IC & 29-story Emerald-Shapery Cnt \\
\hline u & Pomerado Hospital \\
\hline IC & Miles Laboratories \\
\hline IC & Cineplex-odeon theater \\
\hline
\end{tabular}

Sonora

Madera

Tulare

Tulare

Porterville

Hanford

Bakersfield

Edwards AFB

Apple Valley

Santa Barbara

Thousand Oaks

Simi Valley

Los Angeles

Los Angeles

Los Angeles

El Segundo

El Segundo

Harbor Cily

Long Beach

Long Beach

San Bernardino

Riverside

Brea

Garden Grove

Santa Ana

Fullerton

Tustin

Irvine

Laguna Hills

Costa Mesa

El Toro

Hemet

Carlsbad

Escondido

Escondido

Coronado

San Diego

San Diego

San Dlego

San Diego

San Diego

San Diego

San Diego

San Diego

San Diego

San Diego

San Diego

San Diego

San Diego

San Diego

San Diego

Poway

Covina

Universal City
9

76

AS,AN

I(7/86)

$1(7 / 86)$

I(7/86)

EP

I(9/86)

$1(7 / 86)$

1(?)

66

456

1200

420

960

600

32

50

420

168

530

240

390

10

110

18

400

555

AN,CN

AN

$\mathrm{CN}$

AN

$36 \quad A N$

I(?)

I(?)

AN,AS

EP

1(2/87), EP

2000

$1(7 / 86)$

AN

AN

AN

SD,AN

AN

AN

I(5/87)

500

E

19.9

$200 \quad E$

$85 \quad 84$

92

85

4

13

6
AN

AN

$A N, S D(?)$

AN,SD

AN,SD

SD

I(7/86),AN

98

$I(1 / 87)$

50

I(5/87)

I(5/87) 


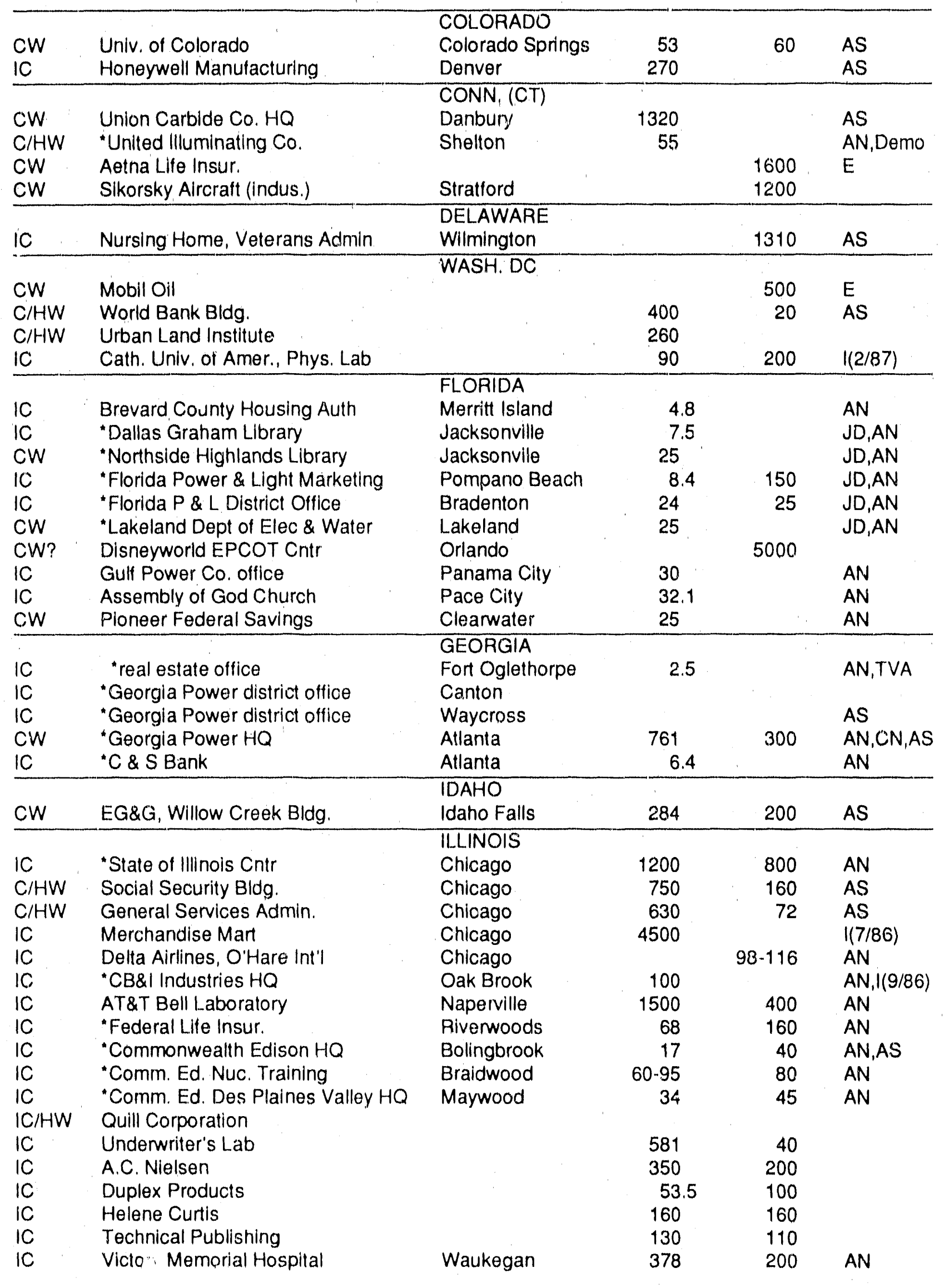




\begin{tabular}{|c|c|c|c|c|c|}
\hline $\begin{array}{l}\text { IC } \\
\text { IC } \\
\text { IC } \\
4 \\
\text { C/HW } \\
\text { C/HW } \\
\text { IC }\end{array}$ & $\begin{array}{l}\text { Epstein \& Sons Publishing Co. } \\
\text { "Mlicro-Swltch Bldg. } \\
\text { Rand McNally Bldg. } \\
\text { Plaza Towers } \\
\text { St. Charles High School } \\
\text { Whealon College, Graham Cntr } \\
\text { unknown }\end{array}$ & $\begin{array}{l}\text { Barrington } \\
\text { Freeport } \\
\text { Skokie } \\
\text { Schaumberg } \\
\text { St. Charies } \\
\text { Wheaton } \\
\text { Rockford } \\
\end{array}$ & $\begin{array}{r}135 \\
60-300 \\
277 \\
851 \\
221 \\
185 \\
800 \\
\end{array}$ & $\begin{array}{r}68 \\
200-240\end{array}$ & $\begin{array}{l}\text { AN } \\
\text { AN } \\
\text { AS,AN } \\
\text { AS } \\
\text { AS, } 1(2 / 87) \\
1(2 / 87) \\
\end{array}$ \\
\hline CW & McCormick Plano Co. & $\begin{array}{l}\text { INDIANA } \\
\text { Fort Wayne }\end{array}$ & 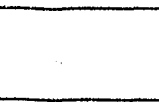 & & \\
\hline $\begin{array}{l}\text { CW } \\
\text { CW } \\
\text { CW }\end{array}$ & $\begin{array}{l}\text { IBM Office Bldg. } \\
\text { Human Resources } \\
\text { Toyota Auto Mig plant }\end{array}$ & $\begin{array}{l}\text { KENTUCKY } \\
\text { Lexington } \\
\text { Frankfort }\end{array}$ & $\begin{array}{c}\text { central } \\
440\end{array}$ & $\begin{array}{r}400 \\
3500\end{array}$ & $\begin{array}{l}\text { AS } \\
1(7 / 86)\end{array}$ \\
\hline IC & Capital Bldg. \& Loan & $\begin{array}{l}\text { LOUISIANA } \\
\text { Baton Rouge }\end{array}$ & & & AS \\
\hline $\begin{array}{l}\text { IC } \\
\text { C/HW } \\
\text { C/HW } \\
\text { IC } \\
\text { IC } \\
\text { IC } \\
\text { CW } \\
\text { IC } \\
\text { IC }\end{array}$ & $\begin{array}{l}\text { Urion Trust Company } \\
\text { Ist Federal Reserve Bank } \\
\text { GSA Bldg., Metro West } \\
\text { "Balt. Gas \& Electric HQ } \\
\text { Martln Murietta } \\
\text { Gould Electronics } \\
\text { "PEPCO Service Cntr } \\
\text {-PEPCO Service Cntr } \\
\text { St. Ambrose Church }\end{array}$ & $\begin{array}{l}\text { MARYLAND } \\
\text { Baltimore } \\
\text { Baltimore } \\
\text { Baltimore } \\
\text { Baltimore } \\
\text { Baltimore } \\
\text { Baltimore } \\
\text { Forestville } \\
\text { Rockville } \\
\text { Cheverly }\end{array}$ & $\begin{array}{r}230 \\
1600 \\
175 \\
\\
22 \\
38\end{array}$ & $\begin{array}{r}40 \\
168 \\
126 \\
26\end{array}$ & $\begin{array}{l}\text { CN,AN } \\
\text { AS }\end{array}$ \\
\hline $\begin{array}{l}\mathrm{C} / \mathrm{HW} \\
\mathrm{IC} \\
\mathrm{C} / \mathrm{HW} \\
\mathrm{IC} \\
\mathrm{IC}\end{array}$ & $\begin{array}{l}\text { MA State Transportn. Bldg } \\
\text { IBM \& Arkwright Insur. } 450 \\
\text { Brushhill System Office } \\
\text { Haemonetics Corporation } \\
\text { Adams Russel }\end{array}$ & $\begin{array}{l}\text { MASS. (MA) } \\
\text { Boston } \\
700 \\
\text { West Springfield } \\
\text { Bralntree } \\
\text { Amesbury } \\
\end{array}$ & $\begin{array}{r}1(5 / 87) \\
73.4\end{array}$ & $\begin{array}{r}8 \\
84 \\
84\end{array}$ & $\begin{array}{l}\text { AS } \\
\text { AS }\end{array}$ \\
\hline $\begin{array}{l}\text { CW } \\
\mathrm{CW} \\
\mathrm{CW}\end{array}$ & $\begin{array}{l}\text { Univ of Michigan Med. Cnir } \\
\text { General Motors Corp. (indus.) } \\
\text { Michlgan State Univ. }\end{array}$ & $\begin{array}{l}\text { MICHIGAN } \\
\text { Ann Arbor } \\
\text { Detroit (Pontiac) } \\
\text { Detroit }\end{array}$ & & $\begin{array}{r}1500 \\
300-350\end{array}$ & $\begin{array}{l}l(9 / 86) \\
E\end{array}$ \\
\hline $\begin{array}{l}\text { C/HW } \\
\text { CW } \\
\text { C/HW } \\
\text { C/HW } \\
\text { C/HW } \\
\text { CW }\end{array}$ & $\begin{array}{l}\text { St. Paul Co. General Services } \\
\text { Donaldson Corporation } \\
\text { American Family Insur. \#1 } \\
\text { Alnerican Family Insur. \#2 } \\
\text { Equitable Life Insur. Bldg } \\
\text { CDC Distribution Cntr }\end{array}$ & $\begin{array}{l}\text { MINN: (MN) } \\
\text { Woodbury } \\
\text { Bloomington } \\
\text { Eden Prairie } \\
\text { Eden Prairie } \\
\text { Minnetonka } \\
\text { St. Paul }\end{array}$ & $\begin{array}{r}80 \\
165 \\
60 \\
51 \\
72\end{array}$ & $\begin{array}{r}40 \\
200 \\
15 \\
12 \\
80\end{array}$ & $\begin{array}{l}\text { AS } \\
\text { AS } \\
\text { AS } \\
\text { AS } \\
\text { AS }\end{array}$ \\
\hline CW & Marion Laboratories & $\begin{array}{l}\text { MISSOURI } \\
\text { Kansas City }\end{array}$ & & & \\
\hline $\begin{array}{l}\text { C/HW } \\
\text { IC } \\
\text { C/HW } \\
\text { C/HW } \\
\text { C/HW } \\
\text { C/HW }\end{array}$ & $\begin{array}{l}\text { "Electronics Associates } \\
\text { Enerplex complex } \\
\text { GPU office } \\
\text { AT \& T Branch Office } \\
\text { Prudential Bldg } \\
\text { Perkin-Elmer Corporation }\end{array}$ & $\begin{array}{l}\text { NEW JERSEY } \\
\text { West Long Branch } \\
\text { Plainesboro } \\
\text { Parsipanny } \\
\text { Basking Ridge } \\
\text { Iselin } \\
\text { Ocean Port }\end{array}$ & $\begin{array}{r}320 \\
130 \\
125 \\
2500 \\
248 \\
80\end{array}$ & $\begin{array}{r}150 \\
300 \\
60 \\
24 \\
20\end{array}$ & $\begin{array}{l}\text { AN } \\
\text { AN } \\
\text { AN } \\
\text { AN } \\
\text { AN } \\
\text { AN }\end{array}$ \\
\hline $\mathrm{C} / \mathrm{HW}$ & Univ of New Mexico, ME bldg & $\begin{array}{l}\text { NEW MEXICO } \\
\text { Albuquerque }\end{array}$ & 60 & 120 & AS \\
\hline
\end{tabular}




\begin{tabular}{|c|c|c|c|c|c|}
\hline $\begin{array}{l}\text { CW } \\
C W \\
C / H W \\
u\end{array}$ & $\begin{array}{l}\text { Univ of New Mexico } \\
\text { Presbyterian Hospltal } \\
\text { Public Service of New Mexico } \\
\text { Copper Square }\end{array}$ & $\begin{array}{l}\text { Albuquerque } \\
\text { Albuquerque } \\
\text { Albuquerque } \\
\text { Albuquerque }\end{array}$ & $\begin{array}{l}396 \\
278 \\
\text { AS } \\
\end{array}$ & $\begin{array}{r}16 \\
360 \\
300\end{array}$ & $\begin{array}{l}\text { AS } \\
\text { AS }\end{array}$ \\
\hline $\begin{array}{l}\mathrm{CW} \\
\mathrm{CW} \\
\mathrm{CW} \\
\mathrm{CW} \\
\mathrm{CW} \\
\mathrm{CW} \\
\mathrm{C} / \mathrm{HW} \\
\mathrm{C} / \mathrm{HW} \\
\mathrm{C} / \mathrm{HW} \\
\mathrm{C} / \mathrm{HW} \\
\mathrm{C} / \mathrm{HW} \\
\mathrm{IC}\end{array}$ & $\begin{array}{l}\text { Battery Park offlce } \\
\text { HJ Kalikow, } 101 \text { Park Ave } \\
42 \text { story tower } \\
\text { Bloomington Store } \\
\text { New York Univ. } \\
\text { offlce building } \\
\text { C.H. Stewart HQ } \\
\text { Clty Hall } \\
\text { R. F. Communications } \\
\text { School \#19 } \\
\text { WHEC TV (Ch 10) Bldg } \\
\text { Albany County Clvic Cnt }\end{array}$ & $\begin{array}{l}\text { NEW YOAK } \\
\text { New York } \\
\text { New York } \\
\text { New York } \\
\text { New York } \\
\text { New York } \\
\text { White Plains } \\
\text { Newark } \\
\text { Rochester } \\
\text { Rochester } \\
\text { Rochester } \\
\text { Rochester } \\
\text { Albany }\end{array}$ & $\begin{array}{r}170 \\
250 \\
140 \\
130 \\
103 \\
30\end{array}$ & $\begin{array}{r}3500 \\
300-350 \\
500 \\
1000 \\
4000 \\
\\
60 \\
20 \\
30 \\
20 \\
10\end{array}$ & $\begin{array}{l}\text { AS } \\
E \\
E \\
E \\
1(8 / 86) \\
\text { AS } \\
\text { AS } \\
\text { AS }\end{array}$ \\
\hline $\begin{array}{l}\mathrm{CW} \\
\mathrm{IC} / \mathrm{HW} \\
\mathrm{IC} \\
\mathrm{CW} \\
\mathrm{CW} \\
\mathrm{CW} \\
\mathrm{CW}\end{array}$ & $\begin{array}{l}\text { Sun Valley Middle School } \\
\text { Beaufort Middle School } \\
\text { Nash Central School } \\
\text { IBM regional offlice } \\
\text { Douglas Municipal Airport } \\
\text { Liberty Llie HQ } \\
\text { University of NC } \\
\end{array}$ & $\begin{array}{l}\text { NORTH CAR. } \\
\text { Monroe } \\
\text { Beaufort } \\
\text { Nashville } \\
\text { Charlotte } \\
\text { Charlotte } \\
\text { Charlotte } \\
\text { Raleigh } \\
\end{array}$ & $\begin{array}{l}54.4 \\
52\end{array}$ & $\begin{array}{r}500 \\
60 \\
180 \\
4,70\end{array}$ & $\begin{array}{l}A S \\
E \\
E \\
E\end{array}$ \\
\hline $\begin{array}{l}\text { IC } \\
\text { IC } \\
\mathrm{CW} \\
\mathrm{CW} \\
\end{array}$ & $\begin{array}{l}\text { Akron Baptist Temple } \\
\text { Ohio Edison Bldg. } \\
\text { Youngstown General Hospltal } \\
\text { Youngstown State Univ. }\end{array}$ & $\begin{array}{l}\text { OHIC } \\
\text { Akron } \\
\text { Ravenna } \\
\text { Youngstown } \\
\text { Youngstown }\end{array}$ & $\begin{array}{l}40 \\
2.6\end{array}$ & $\begin{array}{l}101) \\
C .2 \\
240 \\
800\end{array}$ & $\begin{array}{l}\text { AS } \\
\text { AS } \\
l(7 / 86) \\
E\end{array}$ \\
\hline CW & Halliburton Services Lab & $\begin{array}{l}\text { OKLAHOMA } \\
\text { Duncan }\end{array}$ & 280 & 500 & AN \\
\hline CW & Tektronix, Inc. & $\begin{array}{l}\text { OREGON } \\
\text { Portland }\end{array}$ & & 1000 & $E$ \\
\hline $\begin{array}{l}\mathrm{IC} / \mathrm{HW} \\
\mathrm{IC} / \mathrm{HW} \\
\mathrm{IC/HW} \\
\mathrm{IC}\end{array}$ & $\begin{array}{l}\text { Metropolitan Edison } \\
\text { Millville Mutual Insur. } \\
\text { Girton Manufacturing } \\
\text { PA Power \& Light Info Cntr }\end{array}$ & $\begin{array}{l}\text { PENN. } \\
\text { Hamburg } \\
\text { Millville } \\
\text { Millville } \\
\text { Limmerick }\end{array}$ & $\begin{array}{r}6 \\
10 \\
10 ?\end{array}$ & 15 & $\begin{array}{l}\text { AS } \\
\text { AS,AN } \\
\text { AS }\end{array}$ \\
\hline IC & "Gilbane building & $\begin{array}{l}\text { RHODE IS. } \\
\text { Providence } \\
\end{array}$ & $90^{?}$ & 60 & AS \\
\hline CW & Mack Truck Inc. (indus.) & SOUTHCAR. & 800 & & \\
\hline $\begin{array}{l}\mathrm{C} / \mathrm{HW} \\
1 \mathrm{C} \\
\mathrm{IC} \\
\mathrm{CW} \\
\mathrm{CW} \\
\mathrm{IC} \\
\mathrm{IC} \\
\end{array}$ & $\begin{array}{l}\text { Soddy High School } \\
\text { West End Furniture } \\
\text { "Merita Bread Store } \\
\text { Karns high school } \\
\text { Oliver Springs elementary school } \\
\text { "film lab } \\
\text { "Madison County Health Clinic }\end{array}$ & $\begin{array}{l}\text { TENN. } \\
\text { Soddy-Daisy } \\
\text { Knoxville } \\
\text { Knoxville } \\
\text { Knoxville } \\
\text { Knoxville } \\
\text { Chattanooga } \\
\text { Jackson } \\
\end{array}$ & $\begin{array}{r}140 \\
4 \\
3\end{array}$ & $\begin{array}{l}150 \\
100\end{array}$ & $\begin{array}{l}\text { AN } \\
\text { AN } \\
\text { AN } \\
\text { E } \\
\text { AN } \\
\text { AN }\end{array}$ \\
\hline CW & The Crescent & $\begin{array}{l}\text { TEXAS } \\
\text { Dallas }\end{array}$ & 1500 & & AN \\
\hline
\end{tabular}




\begin{tabular}{|c|c|c|c|c|c|}
\hline $\mathrm{CW}$ & Intertirst Plaza/Dallas Main & Dallas & 200 & & AN \\
\hline $\mathrm{CW}$ & Thanksgiving Tower & Dallas & 1500 & & AN \\
\hline CW & North Park IV East & Dallas & 530 & 300 & AN \\
\hline CW & *Haggar Compäny & Dallas & 73 & & AN \\
\hline $\mathrm{CW}$ & Walnut Green Offlces & Dallas & 164 & & AN \\
\hline $\mathrm{CW}$ & Lincoln Centre II \& III & Dalias & 1232 & $10 C 0$ & AN \\
\hline CW & Lincoln Centre IV & Dallas & & 800 & $E$ \\
\hline 10 & Southland Corporation & Dallas & & & \\
\hline IC & Dallas Power \& Llght & Dallas & & & \\
\hline CW & Opera House & Dallas & & 500 & $E$ \\
\hline CW & Placid Elm offlce & Dallas & 1000 & 500 & E \\
\hline CW & Prudentlal Realty & Dallas & & 600 & E \\
\hline IC & Sunbelt Corp. HQ & Dallas & 550 & 600 & $(1 / 2 / 87)$ \\
\hline lc & Eplscopal Church & $\begin{array}{l}\text { Dallas } \\
\text { Dallas }\end{array}$ & 27 & 300 & \\
\hline CW & $\begin{array}{l}\text { Veritas Insur. Co. } \\
\text { Veritas HQ Office }\end{array}$ & $\begin{array}{l}\text { Dallas } \\
\text { Houston }\end{array}$ & & 200 & $F$ \\
\hline CW & P.I.C. Realty & Irving & 555 & & AN \\
\hline IC & unknown & Fort Worth & & 84 & \\
\hline \multirow{3}{*}{ IC/HW } & & VERMONT & \multirow{2}{*}{\multicolumn{2}{|c|}{8.3}} & \\
\hline & Brandon Coils & Brandon & & & AS \\
\hline & & VIRGINIA & \multicolumn{2}{|l|}{.3} & \multirow{8}{*}{$\begin{array}{l}1(2 / 87) \\
1(2 / 87) \\
I(2 / 87) \\
I(2 / 87) \\
I(2 / 87)\end{array}$} \\
\hline $\mathrm{C} / \mathrm{HW}$ & Virginia Electric Power Co. & East Richmond & 18500 & \multirow[b]{2}{*}{$365-420$} & \\
\hline & •Sixth St. Festlval Marketplace & Richmond & 150 & & \\
\hline & "Best Products Bldg. & Richmond & 230 & 170 & \\
\hline u & Health Affairs Blg & Richmont & 60 & & \\
\hline IC & "Christian Broadcasting Network & Virginla Beach & 280 & 168 & \\
\hline & Christlan Broadcasting Com. Cnt & Virginla Beach & 250 & 150 & \\
\hline $\mathrm{C} / \mathrm{HW}$ & Terra Centre & Burke & 69 & & \\
\hline $\mathrm{C} / \mathrm{HW}$ & Terraset Elementary School & Reston & 69 & & \\
\hline $\mathrm{C} / \mathrm{HW}$ & Mobil Oll Corporation & Fairfax & \multirow[t]{2}{*}{660} & 500 & \multirow{2}{*}{$\begin{array}{l}\text { AS } \\
1(2 / 87)\end{array}$} \\
\hline$u$ & County Public Schools & Chesterfield & & & \\
\hline \multirow[t]{2}{*}{ CW } & Farm Credit Banks Bldg. & $\begin{array}{l}\text { WASH. } \\
\text { Spokane }\end{array}$ & \multicolumn{2}{|l|}{2.53} & \multirow{4}{*}{$A S, A N$} \\
\hline & & WISCONSIN & \multirow{2}{*}{\multicolumn{2}{|c|}{16.8}} & \\
\hline $\mathrm{IC} / \mathrm{HW}$ & Madison Technical College & Reedsburg & & & \\
\hline & Oshkosh Cntr & Oshkosh & \multicolumn{2}{|l|}{66.6} & \\
\hline IC & WEPCO-Waukesha Cntr & Waukesha & \multirow[t]{2}{*}{$10.8-35$} & 25 & \multirow[t]{2}{*}{ AS } \\
\hline IC & Trane Company & La Crosse & & 119 & \\
\hline $\mathrm{C} / \mathrm{HW}$ & Cedar Hills School & Oak Creek & & 10 & AS \\
\hline $\mathrm{IC} / \mathrm{HW}$ & Gettys Manufacturing & $r$ wine & \multirow[t]{2}{*}{33} & 112 & AS \\
\hline IC & Calamet Service Cntr & iviıwaukee & & 3.1 & AS \\
\hline IC & WEPCO-Brown Deer Cntr & Milwaukee & \multicolumn{2}{|l|}{35} & AS \\
\hline
\end{tabular}


INTERNATIONAL BUILDINGS

\begin{tabular}{|c|c|c|c|c|c|}
\hline TYPE & BUILDING & LOCATION & $\begin{array}{l}\text { AREA } \\
\left(k f t^{2}\right)\end{array}$ & $\begin{array}{l}\text { SIZE } \\
\text { (kJb|kgal) }\end{array}$ & SOURCE \\
\hline $\begin{array}{l}\mathrm{C} / \mathrm{HW} \\
\mathrm{CW} \\
\mathrm{C} / \mathrm{HW}\end{array}$ & $\begin{array}{l}\text { Alberta Government Telephone } \\
\text { Esso Plaza } \\
\text { Gulf Canada Square }\end{array}$ & $\begin{array}{l}\text { ALBERTA, CN } \\
\text { Calgary } \\
\text { Calgary } \\
\text { Calgary }\end{array}$ & $\begin{array}{l}1200 \\
2000 \\
1300\end{array}$ & $\begin{array}{r}900 \\
800 \\
1000\end{array}$ & $\begin{array}{l}\text { AS } \\
\text { AS } \\
\text { AS }\end{array}$ \\
\hline CW & "Robson Square/Court House & $\begin{array}{l}\text { BRIT. COL., CN } \\
\text { Vancouver } \\
\end{array}$ & 1187 & 870 & AS \\
\hline $\mathrm{CW}$ & Victoria Hospital & $\begin{array}{l}\text { NOVA SCOT, CN } \\
\text { Hallfax }\end{array}$ & & 400 & $E$ \\
\hline $\begin{array}{l}\mathrm{C} / \mathrm{HW} \\
\mathrm{C} / \mathrm{HW} \\
\mathrm{CW} \\
\mathrm{C} / \mathrm{HW} \\
\mathrm{C} / \mathrm{HW} \\
\mathrm{C} / \mathrm{HW} \\
\mathrm{CW} \\
\mathrm{CW} \\
\mathrm{CW} \\
\mathrm{IC} \\
\mathrm{CW} \\
\mathrm{C} / \mathrm{HW} \\
\mathrm{CW} \\
\mathrm{CW} \\
\mathrm{CW} \\
\mathrm{CW} \\
\mathrm{CW} \\
\mathrm{C} / \mathrm{HW} \\
\mathrm{C} / \mathrm{HW} \\
\mathrm{C} / \mathrm{HW} \\
\mathrm{CW} \\
\mathrm{CW}\end{array}$ & $\begin{array}{l}\text { College Park complex } \\
\text { "Hydro Place } \\
\text { Bell Canada Trinlty Square } \\
\text { Publlo Works Canada } \\
\text { Continental Bank } \\
\text { Globe \& Mall Bldg. } \\
\text { IBM HQ offlce } \\
\text { Exchange Tower } \\
\text { Freecool } \\
\text { Revenue Canada } \\
\text { Metro Toronto Federal office } \\
\text { Toronto Federal Office Bldg } \\
\text { Bell Canada } \\
\text { Transport Training Institute } \\
\text { Ontario Hydro Thermal Training } \\
\text { Ministry of Government } \\
\text { Ontario Ministry of Revenue } \\
\text { Barrie Courthouse } \\
\text { Count House/Registry } \\
\text { Ontario Provinclal Bldg } \\
\text { Toyota Auto Mfg. Plant } \\
\text { Market Square }\end{array}$ & $\begin{array}{l}\text { ONTARIO, CN } \\
\text { Toronto } \\
\text { Toronto } \\
\text { Toronio } \\
\text { Toronto } \\
\text { Toronto } \\
\text { Toronto } \\
\text { Toronto } \\
\text { Toronto } \\
\text { Toronto } \\
\text { Toronto } \\
\text { North York } \\
\text { Willowdale } \\
\text { Scarboro } \\
\text { Cornwall } \\
\text { Mlssissauga } \\
\text { Milton } \\
\text { Oshawa } \\
\text { Barrie } \\
\text { Newmarket } \\
\text { Sudbury } \\
\text { Cambridge } \\
\text { St. John? } \\
\end{array}$ & $\begin{array}{r}600-861 \\
1325 \\
300 \\
600 \\
1000\end{array}$ & $\begin{array}{r}500 \\
1600 \\
156-1000 \\
300 \\
800 \\
51 \\
945 \\
500 \\
50 \\
100 \\
300 \\
300 \\
160 \\
100 \\
60 \\
30 \\
240 \\
70 \\
153 \\
180 \\
1000 \\
350 \\
\end{array}$ & $\begin{array}{l}E \\
E \\
E \\
A S \\
A S \\
A S \\
A S \\
A S \\
E \\
A S \\
A S \\
A S \\
E \\
E\end{array}$ \\
\hline $\begin{array}{l}\mathrm{C} / \mathrm{HW} \\
\mathrm{C} / \mathrm{HW}\end{array}$ & $\begin{array}{l}\text { Canadlan Printing Bureau } \\
\text { Gentec Bldg. }\end{array}$ & $\begin{array}{l}\text { QUEBEC, CN } \\
\text { Hull } \\
\text { Quebec Clty }\end{array}$ & $\begin{array}{r}1033 \\
15\end{array}$ & $\begin{array}{r}440 \\
15\end{array}$ & $\begin{array}{l}\text { AS } \\
\text { AS }\end{array}$ \\
\hline CW & -Unlv of Saskatchewan Eng. & $\begin{array}{l}\text { SASK, CN } \\
\text { Saskatoon } \\
\end{array}$ & 150 & $150-300$ & AS \\
\hline $\begin{array}{l}\text { CW } \\
\text { CW } \\
\text { CW } \\
\text { IC }\end{array}$ & $\begin{array}{l}\text { Royal Belge Theatre } \\
\text { Aquitalne HQ } \\
\text { Musee D'Orsay } \\
\text { La Residence }\end{array}$ & $\begin{array}{l}\text { EUROPE } \\
\text { Brussels, Belglum } \\
\text { Paris, France } \\
\text { Paris, France } \\
\text { Geneeva, Switz. }\end{array}$ & & $\begin{array}{r}350-500 \\
300 \\
300 \\
133\end{array}$ & $\begin{array}{l}1(7 / 86) \\
A N \\
I(7 / 86)\end{array}$ \\
\hline $\begin{array}{l}\text { CW } \\
\text { IC } \\
\text { CW } \\
\text { CW } \\
\text { CW } \\
\text { CW } \\
\text { CW } \\
\text { CW }\end{array}$ & $\begin{array}{l}\text { Menlyn Park Shopping Centre } \\
\text { Hollday Inn } \\
\text { Univ. of Natal } \\
\text { Westway Office } \\
\text { Southern Life Office } \\
\text { Small Business Deve!. Corp. } \\
362 \text { West Street } \\
\text { Cowey Park }\end{array}$ & $\begin{array}{l}\text { SO. AFRICA } \\
\text { Praetorla } \\
\text { Praetorla } \\
\text { Durban } \\
\text { Durban } \\
\text { Durban } \\
\text { Durban } \\
\text { Durban } \\
\text { Durban }\end{array}$ & & $\begin{array}{r}600 \\
105 \\
1000 \\
200 \\
350 \\
350 \\
150 \\
250\end{array}$ & $\begin{array}{l}E \\
E \\
E \\
E \\
E \\
E\end{array}$ \\
\hline
\end{tabular}




\begin{tabular}{|c|c|c|c|c|c|}
\hline $\begin{array}{l}C W \\
C W \\
C W \\
C W \\
C W\end{array}$ & $\begin{array}{l}\text { Cowey Centre } \\
\text { Kwazulu Admin. Bldg. } \\
\text { Woolworth Co. HQ } \\
\text { Tyger Valley Shopping Centre } \\
\text { Sanlam }\end{array}$ & $\begin{array}{l}\text { Johannesbourg } \\
\text { Johannesbourg } \\
\text { Capetown } \\
\text { Capetown } \\
\text { Bellville }\end{array}$ & & $\begin{array}{l}150 \\
200 \\
300 \\
300 \\
300\end{array}$ & $\begin{array}{l}E \\
E \\
E \\
E \\
E\end{array}$ \\
\hline $\begin{array}{l}10 \\
u \\
10 \\
10\end{array}$ & $\begin{array}{l}\text { Taiwan World Trade Cntr } \\
\text { Triangle OHlice Tower } \\
\text { Geological Sclence Office } \\
\text { Veteran General Hospital }\end{array}$ & $\begin{array}{l}\text { TAIWAN } \\
\text { Talpel } \\
\text { Talwan } \\
\text { Chu-Toong } \\
\text { Kaohsiung } \\
\end{array}$ & $\begin{array}{r}880 \\
600 \\
26\end{array}$ & $\begin{array}{r}680 \\
32\end{array}$ & $\begin{array}{l}1(2 / 87) \\
1(2 / 87) \\
1(2 / 87) \\
1(2 / 87) \\
\end{array}$ \\
\hline IC & Cltibank & $\begin{array}{l}\text { BAAZIL } \\
\text { Sao Paulo }\end{array}$ & 505.7 & & \\
\hline
\end{tabular}



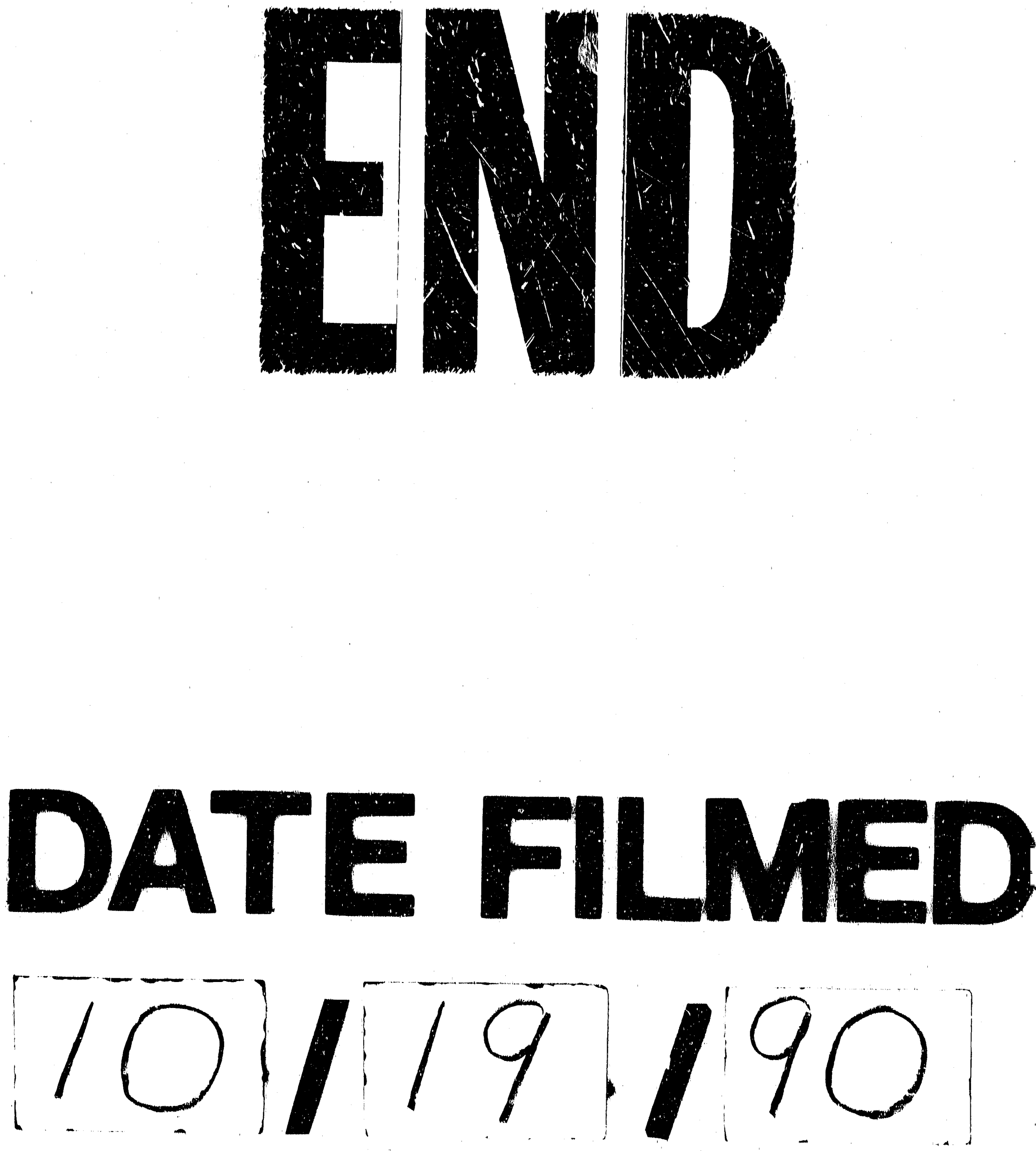
